\title{
Current COVID-19 treatments: Rapid review of the literature
}

\author{
Yijia Dong ${ }^{1}$, Azwa \\ Shamsuddin², Harry \\ Campbell $^{3}$, Evropi \\ Theodoratou ${ }^{3,4}$; \\ on behalf of \\ UNCOVER
}

${ }^{1}$ Edinburgh Medical School, College of Medicine and Veterinary Medicine, The University of Edinburgh, Edinburgh, UK

${ }^{2}$ Centre for Medical Informatics, Usher Institute, The University of Edinburgh, Edinburgh, UK

${ }^{3}$ Centre for Global Health, Usher Institute, The University of Edinburgh, Edinburgh, UK

${ }^{4}$ Cancer Research UK Edinburgh Centre, Medical Research Council Institute of Genetics and Molecular Medicine, University of Edinburgh, Edinburgh, UK

\section{Correspondence to:}

Professor Evropi Theodoratou Centre for Global Health Usher Institute, University of Edinburgh Edinburgh UK e.theodoratou@ed.ac.uk
Background As SARS-CoV-2 continues to spread worldwide, it has already resulted in over 110 million cases and 2.5 million deaths. Currently, there are no effective COVID-19 treatments, although numerous studies are under way. SARS-CoV-2, however, is not the first coronavirus to cause serious outbreaks. COVID-19 can be compared with previous human coronavirus diseases, such as Severe Acute Respiratory Syndrome (SARS) and Middle East Respiratory Syndrome (MERS), to better understand the development of treatments.

Methods Databases Medline, Embase and WHO COVID-19 was systematically searched on 9 February 2021 for studies reporting on therapeutic effect of COVID-19 treatments. Clinical trials, case reports, observational studies and systematic reviews in the English language were eligible.

Results 1416 studies were identified and 40 studies were included in this review. Therapies included are: remdesivir, convalescent plasma, hydroxychloroquine, lopinavir/ ritonavir, interferon, corticosteroids, cytokine storm inhibitors and monoclonal antibodies. Remdesivir, convalescent plasma and interferon seems to provide some clinical benefits such as faster recovery time and reduced mortality, but these effects are not clinically significant. Some corticosteroids are effective in reducing mortality in severe COVID-19 patients. Hydroxychloroquine do not convey any beneficial, and therapies such as cytokine storm inhibitors and monoclonal antibodies were also not effective and require further investigation.

Conclusions There is no single therapy effective against COVID-19. However, a combination of therapies administered at different stages of infection may provide some benefit. This conclusion is reflected in the limited effects of these treatments in previous human coronaviruses.

The World Health Organisation (WHO) declared the coronavirus disease (COVID-19) outbreak as a global pandemic on 12 March 2020. As the novel coronavirus SARS-CoV-2 continues to spread worldwide, it has already resulted in over 110 million cases and 2.5 million deaths. Multiple mutant strains have also complicated the landscape. While numerous studies are under way worldwide to uncover its prevention and cure, there are currently no known therapeutics for COVID-19. SARS-CoV-2, however, is not the first coronavirus to cause serious outbreaks. COVID-19 can be compared with previous human coronavirus diseases, such as Severe Acute Respiratory Syndrome (SARS) and Middle East Respiratory Syndrome (MERS), to better understand the development of treatments. This rapid review with elements of evidence briefing aims to provide a comprehensive overview of current and emerging COVID-19 treatment options based on clinical trials. Finally, we will highlight new emerging therapies and the future prospects of this pandemic. 
Since its discovery in December 2019, the coronavirus SARS-CoV-2 has been responsible for the worldwide COVID-19 pandemic. The coronavirus infects humans through the binding of its spike glycoprotein (S) with the host cell receptor, angiotensin-converting-enzyme 2 (ACE2). Peak viral replication occurs in the initial 7-10 days of infection and the primary immune response occurs in days 10-14. This progresses to either viral clearance or an uncontrolled immune response (cytokine storm) [1]. The time of therapy administration is crucial in determining COVID-19 outcomes. However, with no known cure, as of 8 March 2021, more than 100 million people have been infected and at least 2.5 million have died [2]. In addition, mutant strains have contributed to further uncertainty. The major impact on human health is only one aspect of the pandemic. Public health interventions to "flatten the curve", including nationwide lockdowns, social distancing and travel restrictions, will have lasting effects on the economy, human behaviour and education [3]. Due to the absence of effective treatments and vaccines, current measures are largely reliant on public compliance which have uncertain benefits [4] and puts the world at risk of multiple waves of infections [5]. It is therefore of great interest and urgency that treatments for COVID-19 should be found.

There are currently seven coronaviruses known to infect humans: the endemic HCoV-HKU1, HCoV-OC43, HCoV-NL63 and HCoV-229E which cause 15\% of the cases of the common cold; and the epidemic SARS-CoV, MERS-CoV and SARS-CoV-2 (Table 1). SARS-CoV which caused SARS and MERS-CoV which causes MERS are much more deadly than previous coronaviruses. SARS rapidly spread to 29 countries globally, causing an epidemic with 8096 cases, 774 mortalities and a CFR of 11\% [13]. Likewise, MERS spread to more than 27 countries and as of November 2019 has resulted in 2494 cases and 858 deaths. Its 35\% CFR makes it the deadliest coronavirus to date [27]. As patients acquire immunopathological damage, they can present with dangerous complications such as acute respiratory distress syndrome (ARDS) which developed in around 16\% of SARS [28] and over 50\% of MERS patients [18].

ARDS is a set of pulmonary conditions caused by uncontrolled inflammation, leading to acute respiratory failure. In response to SARS-CoV, MERS-CoV and SARS-CoV-2, the body produces a massive immune response, producing pro-inflammatory neutrophils and cytokines like IL-6, TNF $\alpha$ and IL-1 $\beta$ [29]. This "cytokine storm" attacks lung tissue and pneumocytes to cause vascular leakage and pulmonary fibrosis. Damage to type 1 cells cause decreased perfusion by shunting while damage to type 2 cells puts patients at risk of lung collapse due to decreased surfactant production. Thrombi formation due to activation of the coagulation cascade in response to the fluid exudates further restricts oxygen exchange [30].

SARS-CoV-2 is the first coronavirus to cause a pandemic of its scale in modern times, which could be attributed to a high basic reproduction number (R0). The R0 of COVID-19 is estimated to be 3.77, which is higher than both SARS and MERS [31]. After the incubation period, COVID-19 patients develop moderate symptoms lasting around 5-8 days [32]. Around 5\%-15\% of COVID-19 patients develop ARDS, acute organ failure and shock [33]. The case fatality rate (CFR) varies by country - from less than $0.1 \%$ in Singapore to over 19\% in Yemen [34]. Chest x-rays appear consistent with that of pneumonia, and laboratory findings include lymphopenia, thrombocytopenia, and leukopenia [22]. Similar to SARS and MERS, children are less likely to become infected and present with milder cases [35] whereas older men with co-morbidities have higher mortality [36].

In face of the current crisis, numerous treatments are being tested based on past experience of SARS and MERS. There are 3 common approaches for the discovery of COVID-19 drugs. The first is screening chemical libraries with databases containing large numbers of existing compounds that may have antiviral properties (eg, remdesivir). Second is the testing of existing broad-spectrum antiviral drugs (eg, ribavirin and interferons). The final method involves the de novo development of novel, specific agents such as monoclonal antibodies based on the genomic and biophysical understanding of the SARS-CoV-2 [37]. Development of novel agents takes years and given the urgency of the current pandemic, COVID-19 treatments are mainly repurposed from SARS and MERS.

Promising treatments have been approved for worldwide clinical trials. Remdesivir; Lopinavir/Ritonavir; Interferon $\beta$; hydroxychloroquine and dexamethasone are some of the drugs included in the WHO Solidarity Trial and the Recovery Trial $[38,39]$. Novel vaccines, emerging "cytokine storm" targeting treatments and convalescent plasma therapies are also being explored. Aiming to provide a comprehensive overview of the area of COVID-19 therapeutics, the main objective of this rapid review is to describe existing SARS-CoV-2 therapeutic approaches and present the results of their current COVID-19 clinical trials.

\section{METHODS}

The databases Medline, Embase and WHO COVID-19 were searched for all publications from 2019 to 9 February 2021 using a combination of the terms "COVID 19", "SARSCoV2", "coronavirus", "therapy", "lopina- 
Table 1. Characteristics of coronaviruses that infect humans

\begin{tabular}{|c|c|c|c|c|c|c|c|}
\hline CORONAVIRUS & $\begin{array}{l}\text { DATE } \\
\text { DISCOVERED }\end{array}$ & $\begin{array}{l}\text { DATED } \\
\text { DIVERGED } \\
\text { FROM } \\
\text { COMMON } \\
\text { ANCESTOR }\end{array}$ & $\begin{array}{l}\text { CLASS/ } \\
\text { GENERA }\end{array}$ & SYMPTOMS & TRANSMISSION & $\begin{array}{l}\text { INCUBATION } \\
\text { PERIOD } \\
\text { (DAYS) }\end{array}$ & RISK FACTORS \\
\hline HCoV-229E & $\begin{array}{l}\text { 1966, } \\
\text { Chicago }\end{array}$ & 1800s [6] & Alpha & $\begin{array}{l}\text { Common cold symptoms: } \\
\text { rhinorrhoea, nasal } \\
\text { congestion, sore throat, } \\
\text { headache and chills [7]. } \\
\text { Occurrences of lower } \\
\text { respiratory tract infection } \\
\text { (LRTI) mainly in children } \\
\text { [8] }\end{array}$ & Respiratory & $2-4[7]$ & $\begin{array}{l}\text { Immunocompromised, } \\
\text { children, elderly. }\end{array}$ \\
\hline $\mathrm{HCoV}-\mathrm{OC} 43$ & 1967 & $\begin{array}{l}1850-1900 \\
{[9]}\end{array}$ & Beta & $\begin{array}{l}\text { Common cold symptoms. } \\
\text { Higher rates of LRTI in } \\
\text { adults than HCoV-229E [10] }\end{array}$ & Respiratory & $2-4[7]$ & $\begin{array}{l}\text { Immunocompromised, } \\
\text { children, elderly. }\end{array}$ \\
\hline SARS-CoV & $\begin{array}{l}\text { 2002, } \\
\text { Guangdong }\end{array}$ & $\begin{array}{l}\text { 1985-1998 } \\
{[9]}\end{array}$ & Beta & $\begin{array}{l}\text { Fever, dry cough, headache, } \\
\text { dizziness, rhinorrhoea, } \\
\text { myalgia, chills, rigors, } \\
\text { diarrhoea, vomiting. LRTI, } \\
\text { acute respiratory distress } \\
\text { syndrome (ARDS), shock, } \\
\text { multi-organ failure [11] }\end{array}$ & $\begin{array}{l}\text { Mainly Respiratory. } \\
\text { Faeces-oral, to a lesser } \\
\text { extent [12] }\end{array}$ & $2-7$ [13] & $\begin{array}{l}\text { Advanced age, male } \\
\text { sex [14]. No recorded } \\
\text { deaths in children and } \\
\text { teenagers [11]. }\end{array}$ \\
\hline HCoV-NL63 & $\begin{array}{l}2004, \\
\text { Netherlands }\end{array}$ & 1200s [9] & Alpha & $\begin{array}{l}\text { Common cold symptoms } \\
\text { [7], LRTI [15] }\end{array}$ & Respiratory & $2-4[7]$ & $\begin{array}{l}\text { Immunocompromised, } \\
\text { children, elderly. }\end{array}$ \\
\hline HCoV-HKUl & $\begin{array}{l}2005, \\
\text { Hong Kong }\end{array}$ & 1950s [9] & Beta & $\begin{array}{l}\text { Common cold symptoms } \\
\text { [7], diarrhoea, vomiting } \\
\text { [16], childhood febrile } \\
\text { seizures [17] }\end{array}$ & Respiratory & $2-4[7]$ & $\begin{array}{l}\text { Immunocompromised, } \\
\text { children, elderly, } \\
\text { smoking, inhaled } \\
\text { corticosteroids [16]. }\end{array}$ \\
\hline MERS-CoV & $\begin{array}{l}\text { 2012, } \\
\text { Saudi Arabia }\end{array}$ & 2006 [9] & Beta & $\begin{array}{l}\text { Fever, chills, cough, } \\
\text { myalgia and gastrointestinal } \\
\text { symptoms LRTI, ARDS, } \\
\text { multi-organ failure, renal } \\
\text { failure [18] }\end{array}$ & $\begin{array}{l}\text { Respiratory. Requires } \\
\text { close and prolonged } \\
\text { contact [19] }\end{array}$ & $2-14[20]$ & $\begin{array}{l}\text { Advanced age, male } \\
\text { sex, chronic conditions } \\
\text { (present in } 75 \% \text { of } \\
\text { patients) such as } \\
\text { diabetes, obesity, } \\
\text { hypertension, lung } \\
\text { conditions, cardiac } \\
\text { conditions }[18,21] \text {. }\end{array}$ \\
\hline SARS-CoV-2 & 2019 & $\begin{array}{l}\text { Not } \\
\text { known }\end{array}$ & Beta & $\begin{array}{l}\text { Fever, dry cough, dyspnoea, } \\
\text { myalgia and fatigue [22]. } \\
\text { Less gastrointestinal } \\
\text { involvement than SARS and } \\
\text { MERS [23] }\end{array}$ & $\begin{array}{l}\text { Primarily respiratory } \\
\text { droplets. To a lesser } \\
\text { extent: faecal-ran and } \\
\text { through eyes [24]. } \\
\text { Airborne transmission } \\
\text { during aerosol } \\
\text { generating procedures. } \\
\text { Airborne transmission } \\
\text { in indoor settings with } \\
\text { poor ventilation under } \\
\text { investigation [25] }\end{array}$ & $\begin{array}{l}5-6 \text { d on } \\
\text { average. } \\
\text { Up to } \\
14 \text { d [25] }\end{array}$ & $\begin{array}{l}\text { Advanced age, male } \\
\text { sex. Co-morbidities } \\
\text { (present in } 20 \%-51 \% \text { of } \\
\text { patients): hypertension, } \\
\text { diabetes, cardiovascular } \\
\text { disease, pulmonary } \\
\text { disease and malignancy } \\
\text { [26]. }\end{array}$ \\
\hline
\end{tabular}

vir", "ritonavir", "ribavirin", "remdesivir", "hydroxychloroquine", "corticosteroids", "anakinra", "tocilizumab", "convalescent plasma", "interferon" and "monoclonal antibodies". (Table S1 in the Online Supplementary Document). From the articles retrieved, additional references were identified by a manual search among the cited references and through searching journals online. The types of studies included were clinical trials, case reports, observational studies and systematic reviews. To prevent bias, studies with less than 10 patients were not included. Articles which did not have full text available or were not in English were also excluded.

Data extracted from eligible studies included: Drug/treatment, author, year, study aim, study type, study design, status, main findings and limitations.

The literature search and screening for eligible articles was conducted by 2 reviewers (AS, YD). Data extraction was performed by 2 reviewers (AS, YD). 


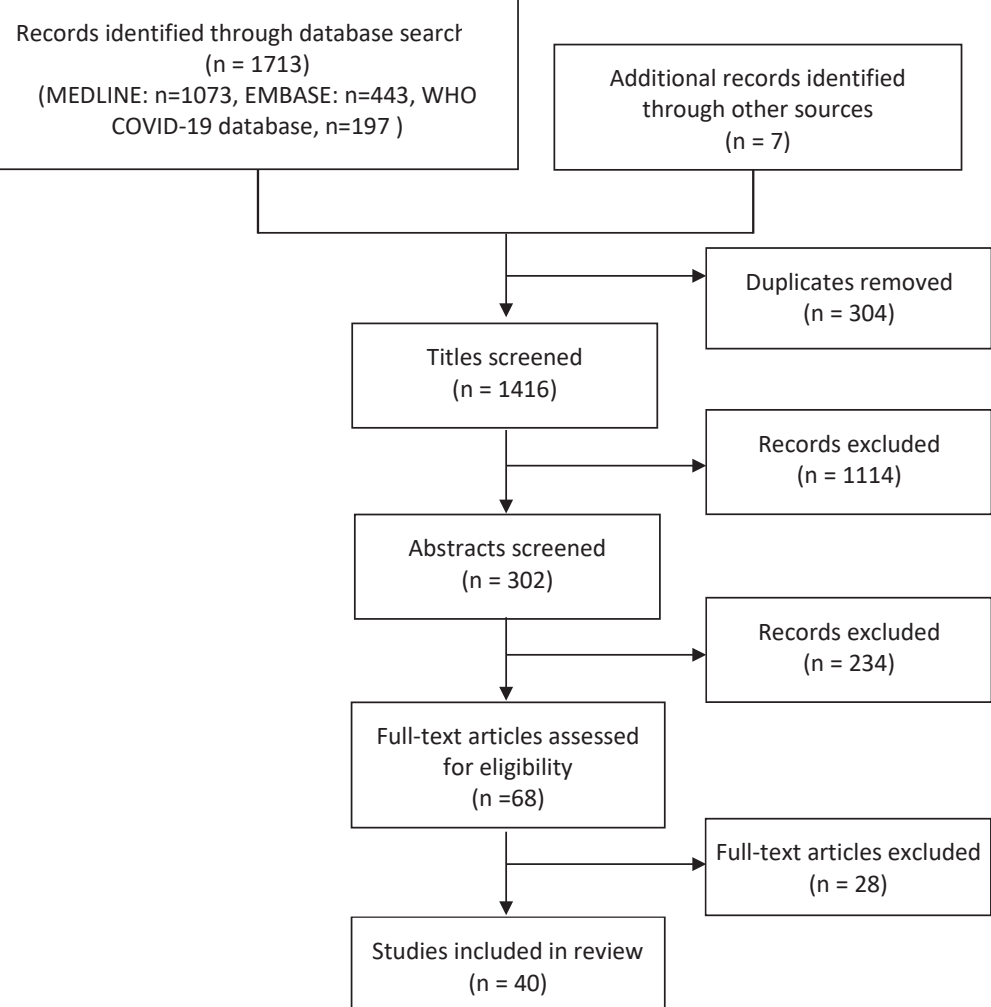

Figure 1. Flowchart summarising study identification and selection.

\section{RESULTS}

After removal of duplicates, the literature search identified 1409 unique articles. A further 7 studies were obtained through manual and citation searches. From the 1416 total articles identified, 1114 were excluded after title review, 234 were excluded after abstract review. Sixty-eight articles were reviewed by full text and a total of 40 articles were selected to be included (Figure 1). This rapid review includes 4 studies on remdesivir, 6 on convalescent plasma, 7 on hydroxychloroquine (Table 2), 2 on lopinavir/ ritonavir, 4 on interferon, 7 on corticosteroids, 6 on cytokine storm inhibitors (Table 3) and 6 on monoclonal antibodies (Table 4). Table 2, Table 3 and Table 4 summarise the studies we reviewed regarding current COVID-19 therapy and trials.

\section{Compounds with anti-viral properties}

\section{Remdesivir}

Remdesivir (GS-5734) is a broad-spectrum nucleoside analogue which is metabolised by the host cell and converted into nucleoside triphosphate (NTP). NTP targets RNA-dependent RNA polymerase (RdRp) which inhibits the transcription of viral RNA [37] (Figure 2). Remdesivir was developed in 2009 by Gilead Sciences [79]. It is most commonly known as a drug to treat Ebola but was proved to be an inferior treatment to other contenders [80].

Remdesivir is currently FDA approved for emergency administration to COVID-19 patients. A study in severe COVID-19 patients showed very positive results. $68 \%$ of patients improved and only $13 \%$ of patients died [40]. These findings are highly significant, considering the mortality of patients with severe COVID-19 is over $40 \%$ [81]. However, viral load was not collected to confirm the antiviral effects and the patient cohort was small and therefore there is a higher chance of false-positive results.

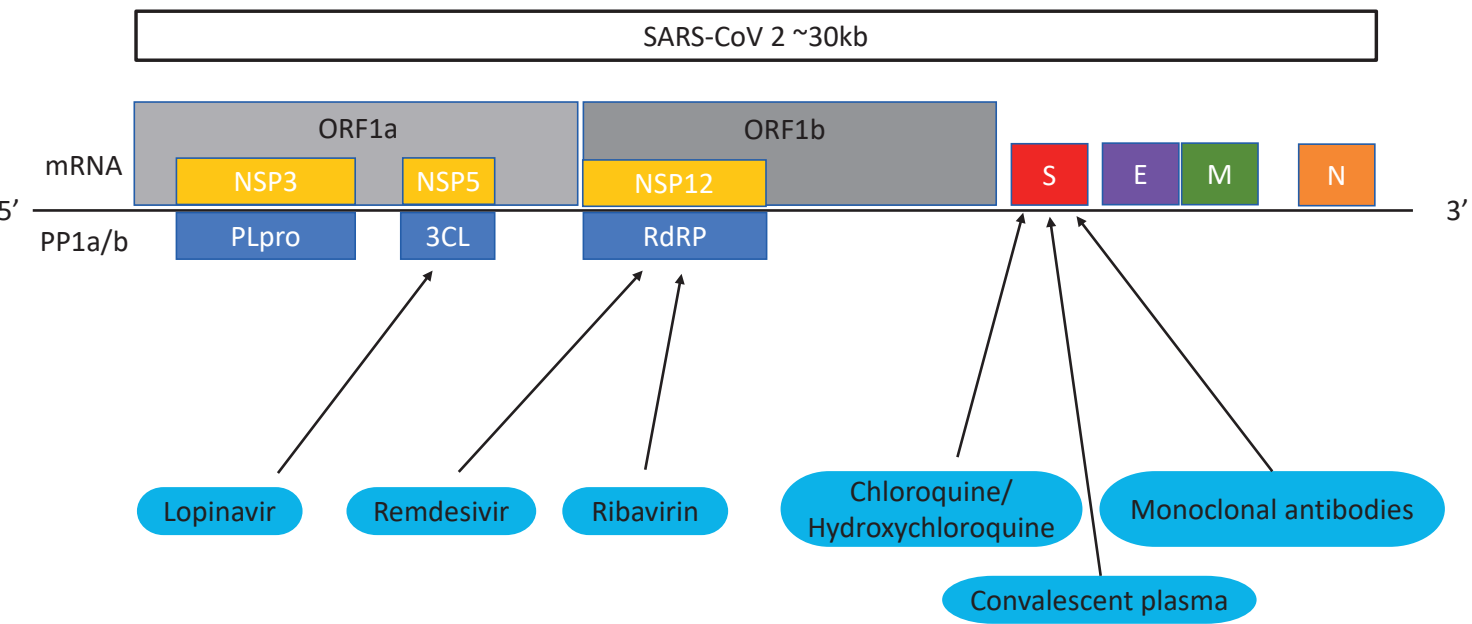

Figure 2. SARS-CoV-2 gene targets. Proteins are translated from the SARS-CoV-2 genome. Lopinavir targets 3CL protease produced by the ORFla gene. Remdesivir and ribavirin targets RNA-dependent RNA polymerase (RdRp) translated from ORF1b. Chloroquine/ hydroxychloroquine, convalescent plasma and monoclonal antibodies have effects against the spike protein. 


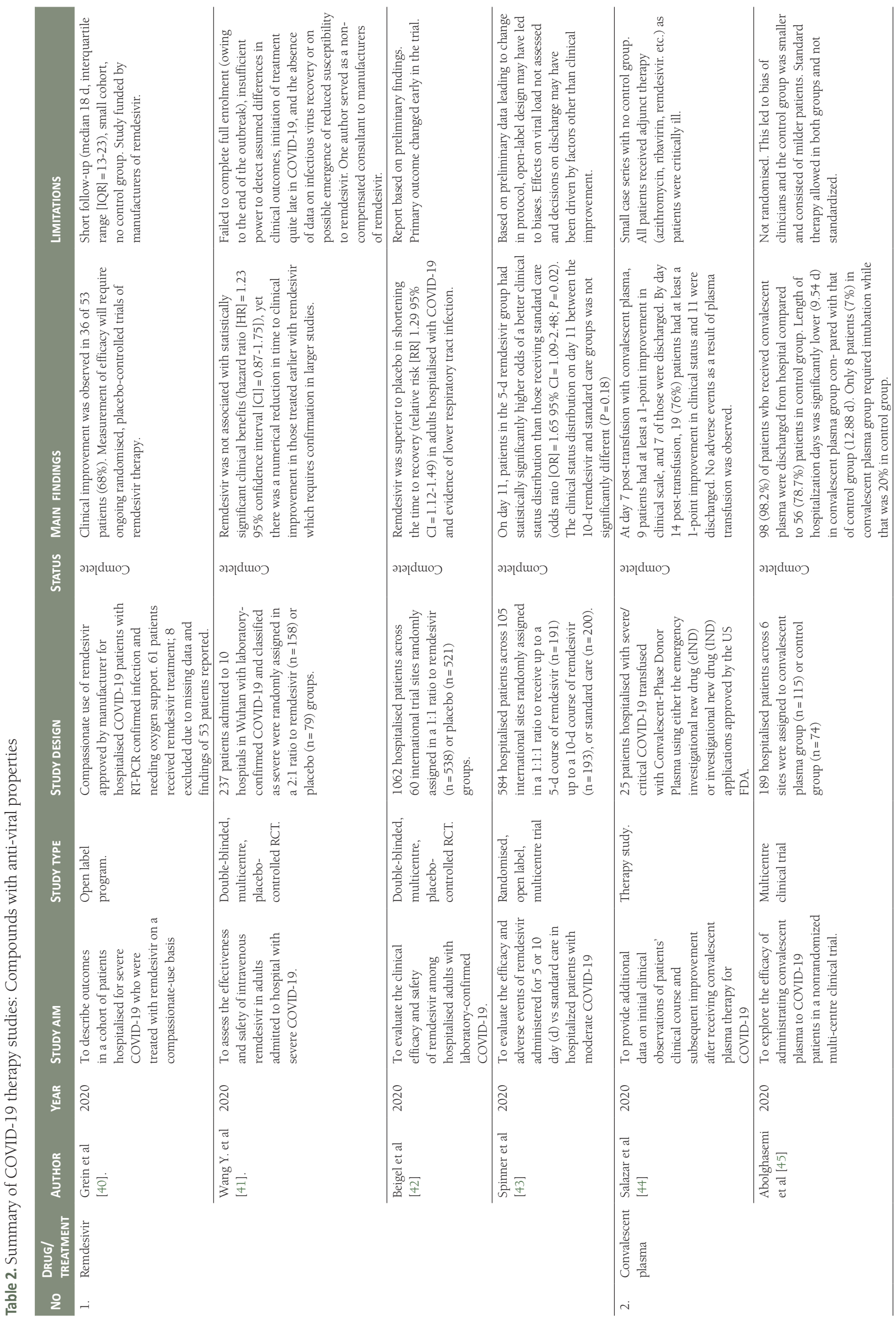




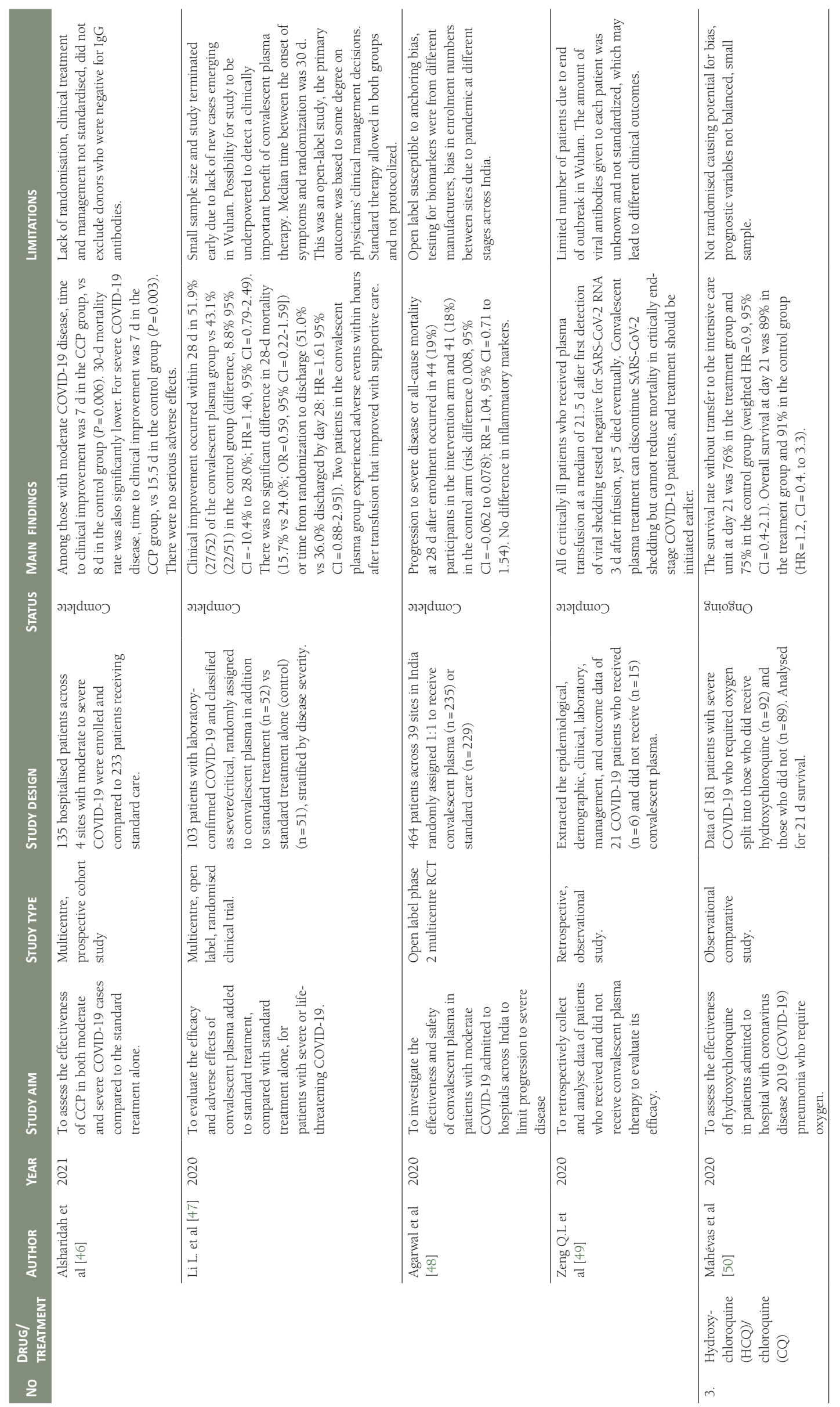




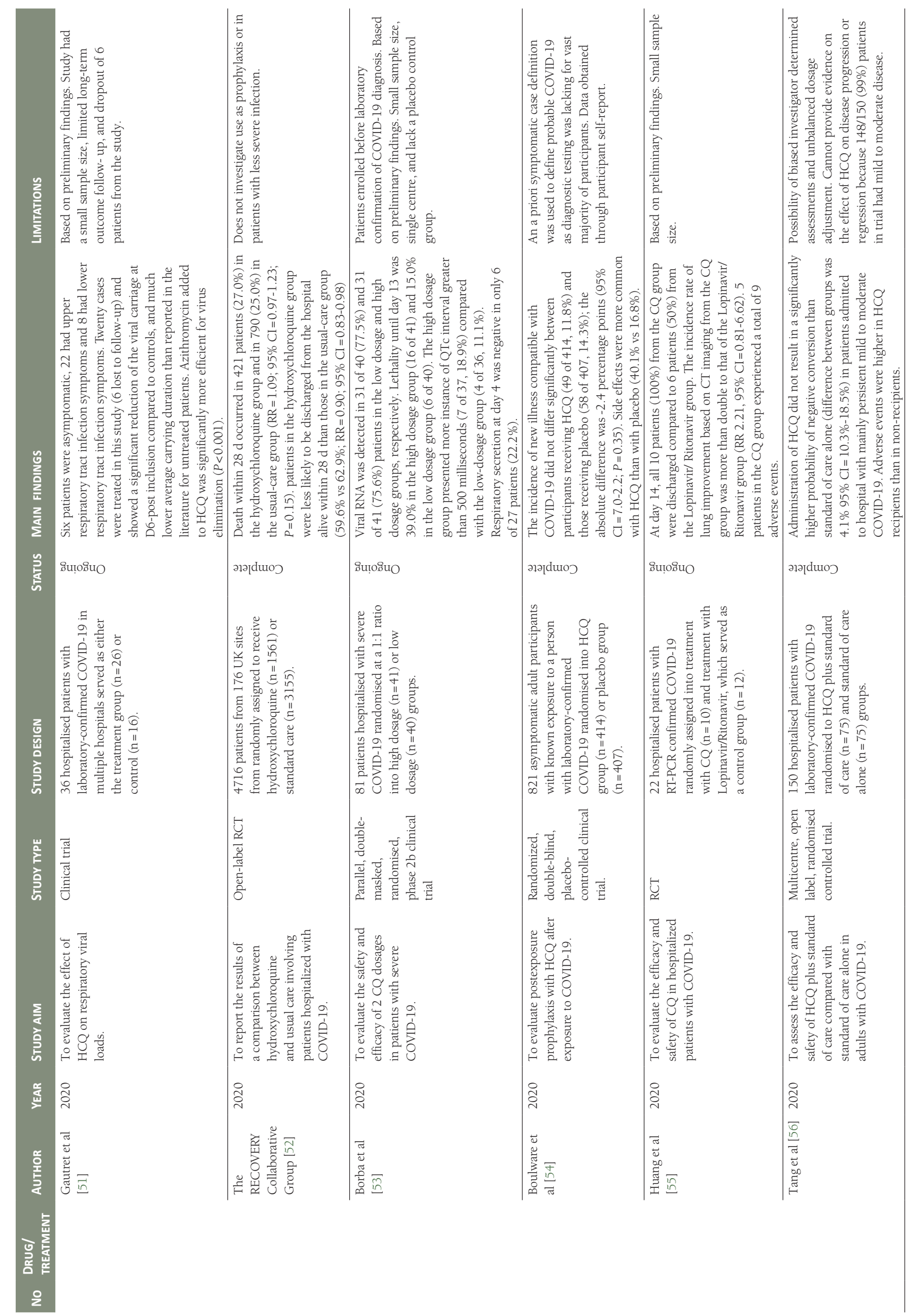




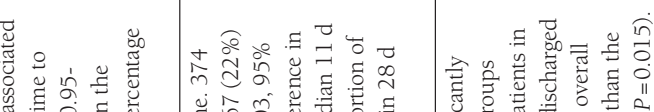

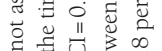

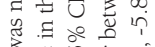

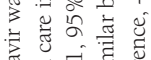

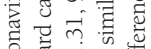
总 要 II 记

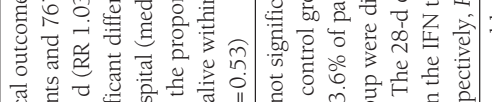

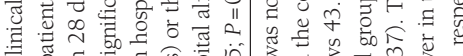

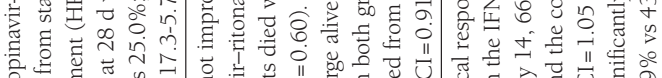

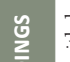

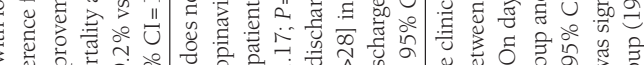

要 年

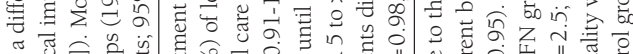

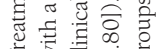

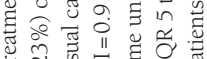

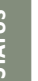

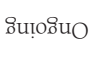

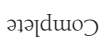

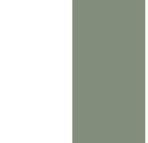

할

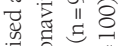

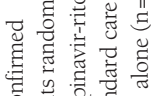

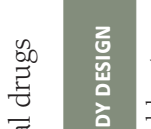

空造运

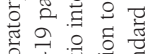

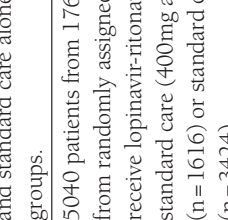

.

焉

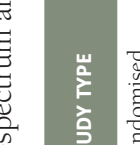

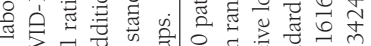

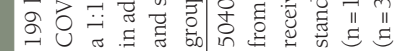

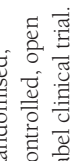

豙

娄

क्षै

悉

जे

字

妾

店

先

走先

善

竞 濖

$\frac{m}{\frac{0}{0}}$ $\frac{\sqrt{2}}{2} \& 3$

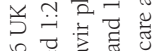

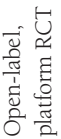

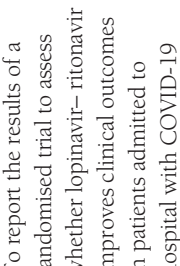

ั̊ำ

高

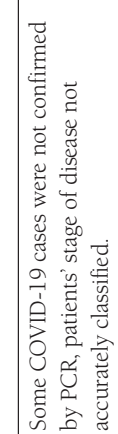

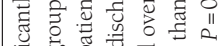
品

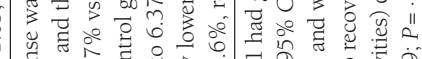

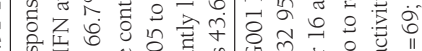

年 bo

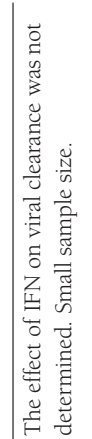

$\exists \quad \exists$

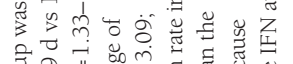

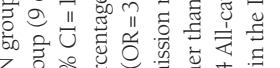

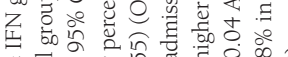

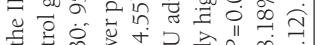

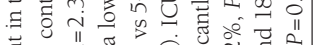

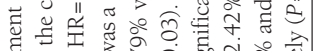

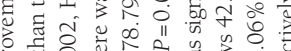

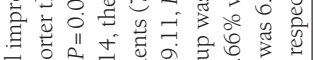

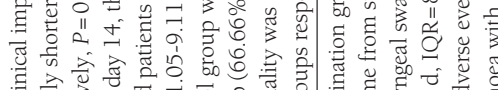

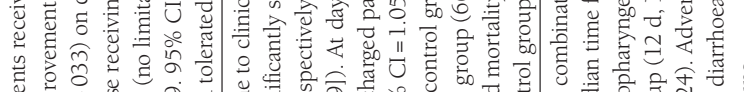

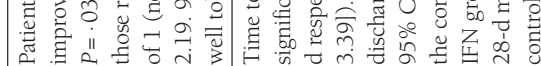

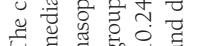

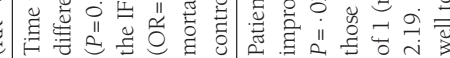

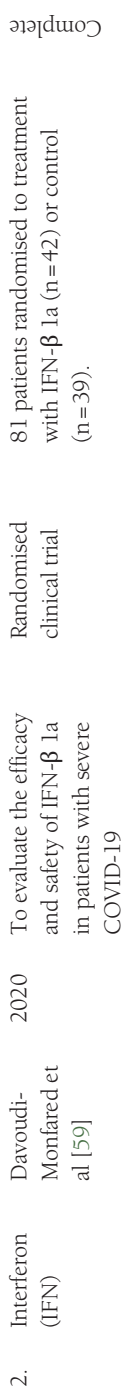

วэวฝนиоว

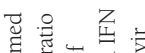

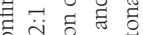

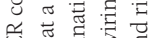
प्र है त व बै है है

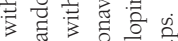
क्ष

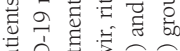

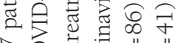

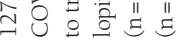

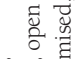

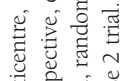
产

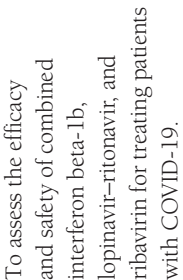
용
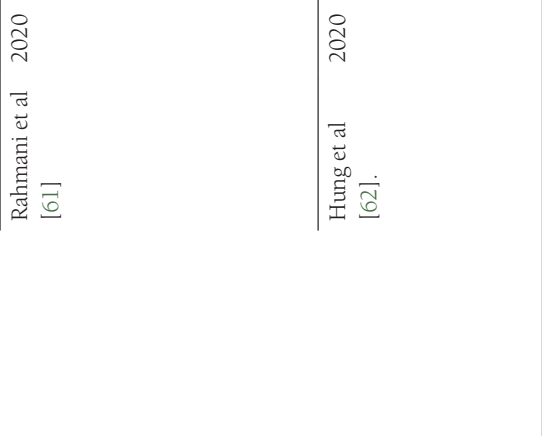


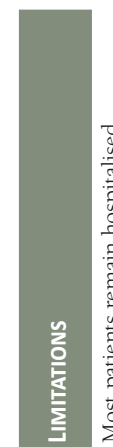

s

旁

วəगdu०ว

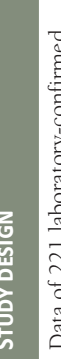

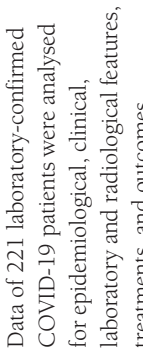
ซु

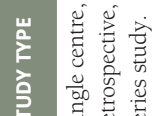

离

宛客

을

证

ร

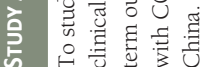

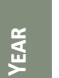

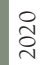

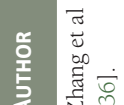

ت্

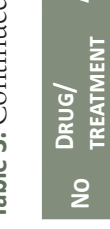

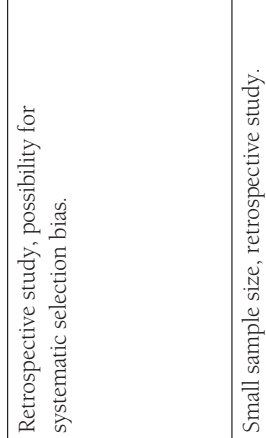
苟

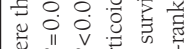

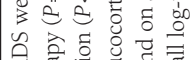

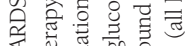
氙它

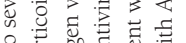

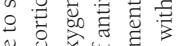

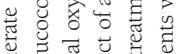

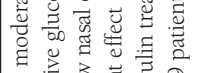
资言藏

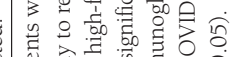

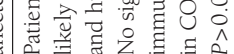

วэฑवน०ว

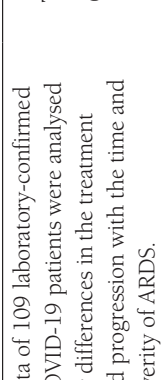

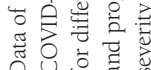

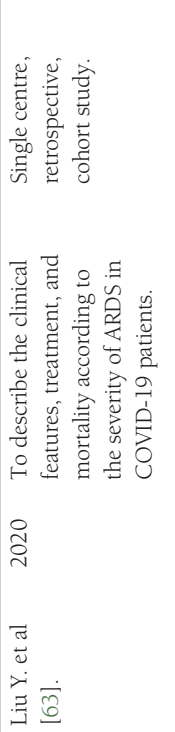

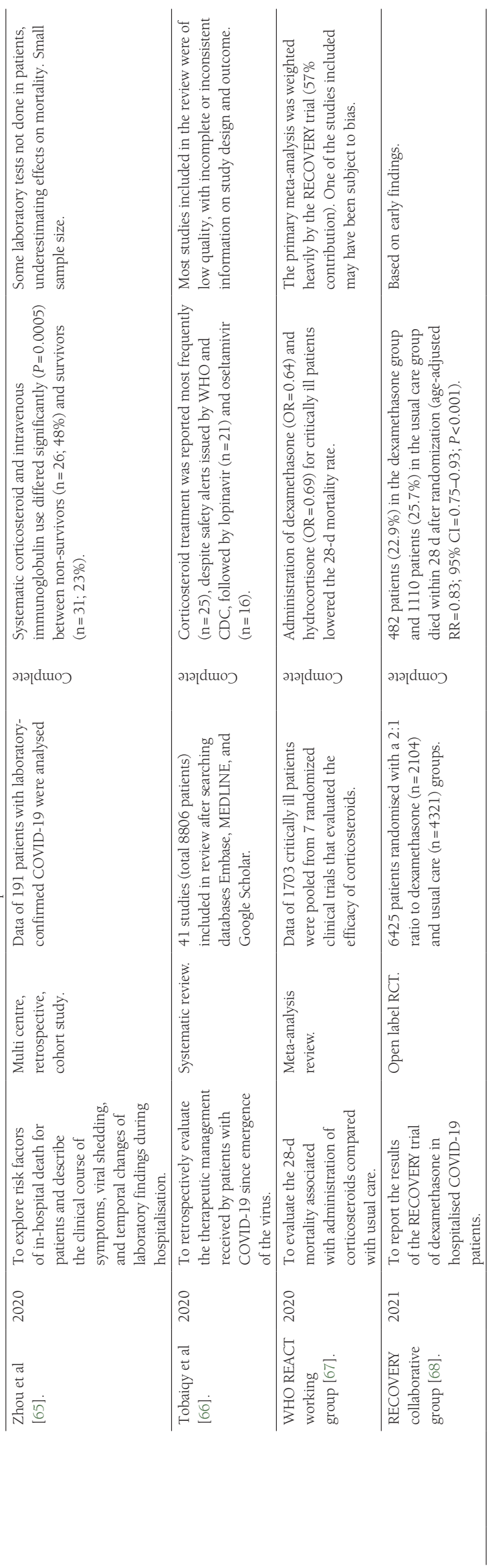




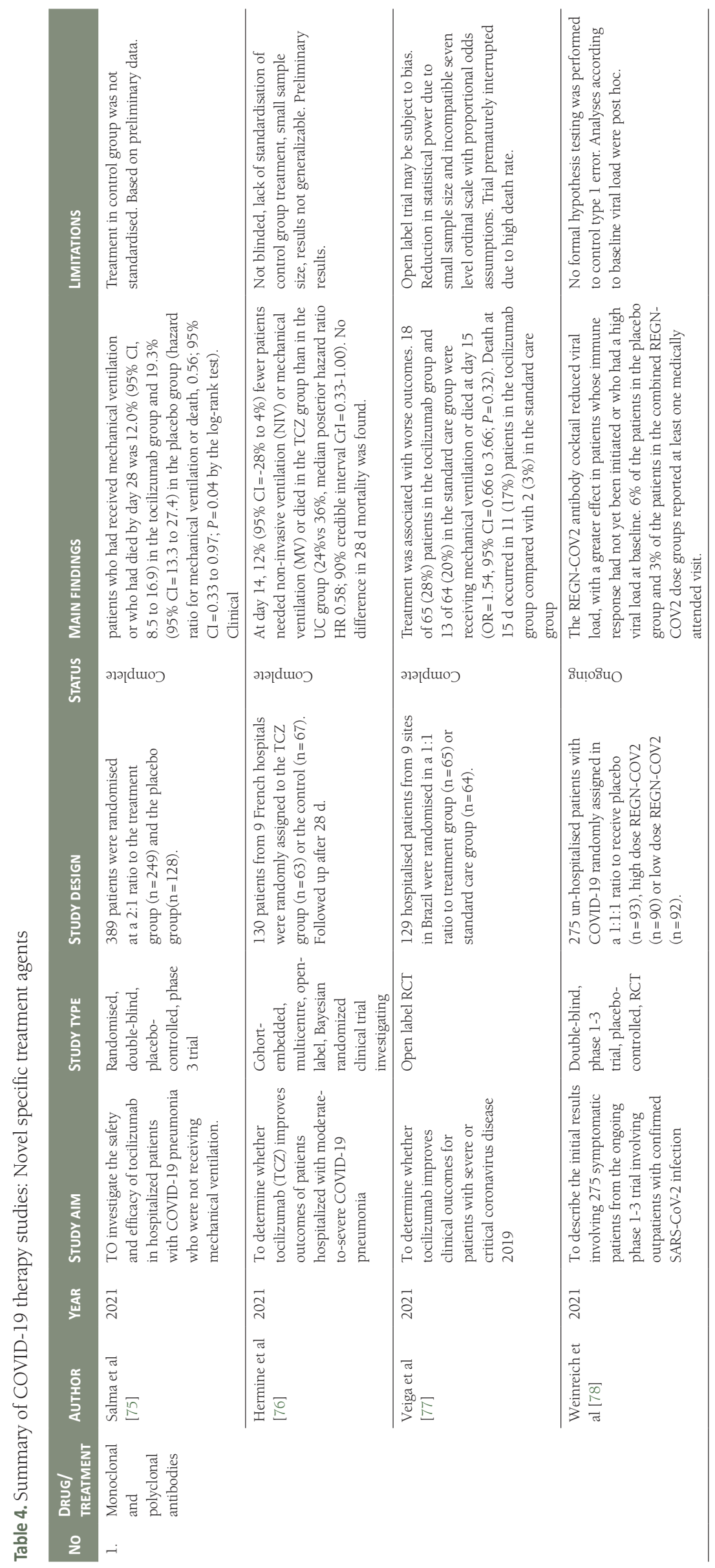


Remdesivir was studied further in a randomised, double-blinded, placebo-controlled trial of 237 patients in which Wang et al reported a statistically insignificant median recovery time of 21 days compared to 23 days in the control [41]. There was no decrease in mortality rate and more patients receiving the treatment dropped out of the trial due to adverse effects which included gastrointestinal symptoms and worsened cardiopulmonary status. This trial did not complete full enrolment. A randomised, placebo-controlled, double-blinded clinical trial of 1062 patients where patients received the same drug dose as the previous study showed that remdesivir had a superior recovery time of 10 days compared to 15 days in the placebo group [42]. Contrary to Wang, this trial found that compared to the placebo, patients who received remdesivir experienced less adverse effects and the mortality rate decreased from $11.9 \%$ to $6.7 \%$. Although this is significant, the high mortality rates reported make it clear that remdesivir alone is unlikely to be sufficient in COVID-19 treatment. This conclusion is supported by the results of a randomised clinical trial which found that despite patients receiving a 5-day course of remdesivir having a significantly better status, it was not clinically important [43]. In accordance with in vivo studies, the drug is most likely only beneficial to patients in the early stages of infection (Figure 3).

\section{Convalescent plasma}

In convalescent plasma (CP) therapy, blood plasma is taken from a patient previously infected by the virus and transfused into a symptomatic patient. The theory is that the antibodies transferred to the symptomatic patient will suppress viremia [1]. Antibodies, or immunoglobins, bind to invading viruses which neutralises the pathogen (Figure 3). It can also cause virus destruction by processes like activating the complement pathway or opsonisation via viral Fc receptors. $\mathrm{CP}$ is generally regarded as safe and has been recorded to be used for the Spanish Flu pandemic as early as 1918 [44] and has been used to treat Machupo virus, Junin, Lassa fever and Ebola virus [1]. It also reduces mortality rates in patients with severe influenza A [82].

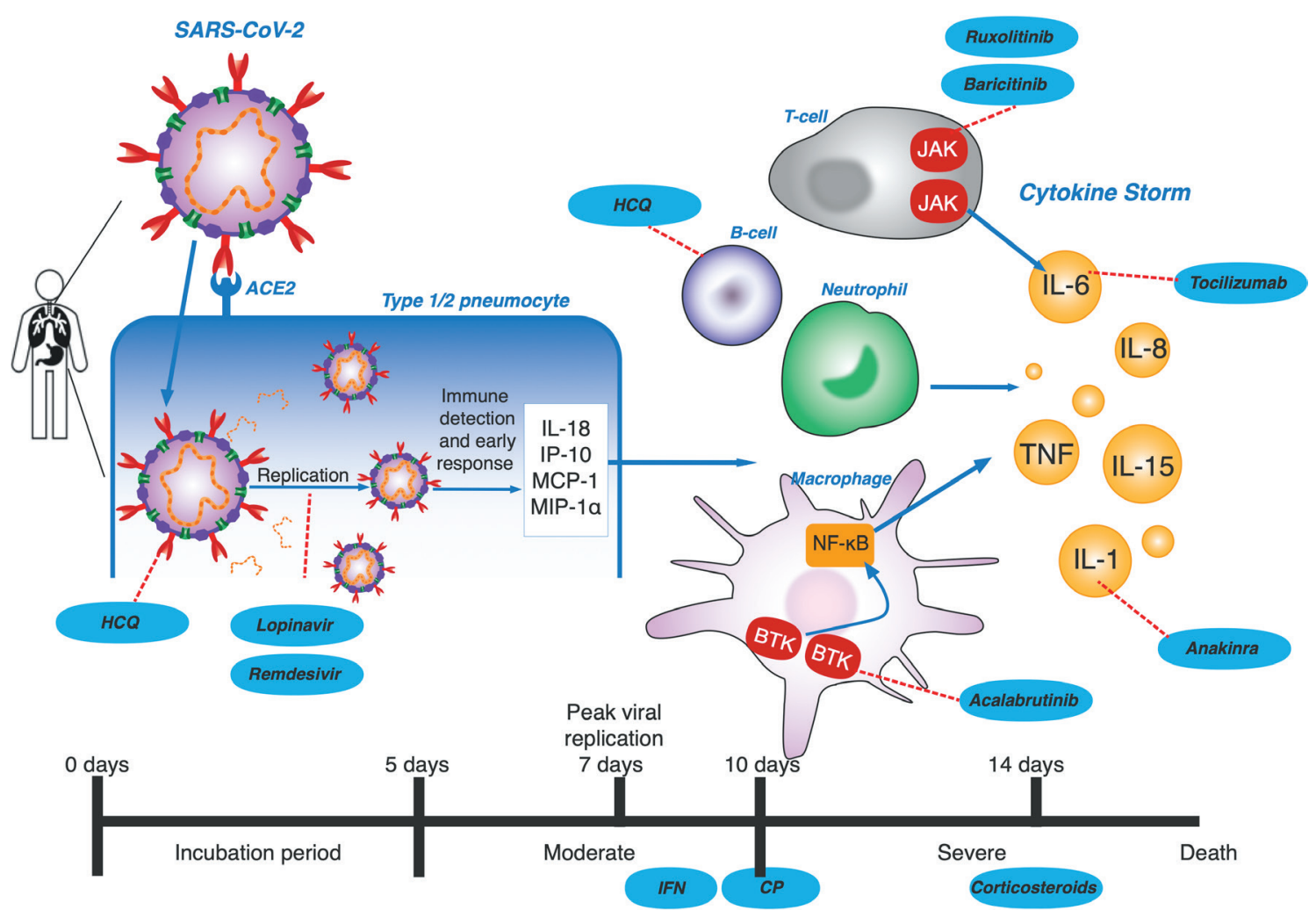

Figure 3. Progression to cytokine storm. Peak viral replication occurs in the initial 7-10 days and primary immune response usually occurs by day 10-14 which is followed by virus clearance [1]. Therefore, therapies appear to be most beneficial when given before 14 days of infection. Days 0-5: incubation period. SARS-CoV-2 enter cell via ACE2 receptors on human type $1 / 2$ pneumocytes and start replicating. Hydroxychloroquine (HCQ) targets glycosylation of viral surface. Lopinavir, remdesivir targets the viral replication. Until day 10: moderate symptoms. The initial immune response produces IL-18, IP-10, MCP-1 and MIP-1 $\alpha$ which starts to recruit specific immune cells. Interferon (IFN), HCQ and convalescent plasma (CP) is most effective. Day 10: severe infection leading to risk of mortality. Macrophages via BTK, T-cells via JAK, neutrophils and B-cells produce cytokines, resulting in a cytokine storm by day 14. Ruxolitinib, baricitinib, tocilizumab, anakinra, acalabrutinib and corticosteroids can be used [1] . 
Convalescent plasma therapy is currently FDA approved to be used in COVID-19 patients for investigational purposes. Observational studies have demonstrated it to be safe and patients treated have a significantly improved oxygen saturation, CRP, 30-day survival rate and reduced need for mechanical ventilation [45,46]. Results also suggest CP could alleviate inflammation and overreaction of the immune system. This potential is further demonstrated by a study which found a $76 \%$ improvement rate in patients, of which more than half had ARDS [44].

A randomised, open label clinical trial was performed on 103 patients with life threatening COVID-19 [47]. Results show that CP therapy was clearly highly effective in viral clearance. Treatment was associated with $87 \%$ negative conversion rate of viral PCR compared to $37.5 \%$ of the control group. Although those patients receiving the treatment had a shorter time to clinical improvement and a lower 28-day mortality rate, these results were found to be statistically insignificant. The study was terminated early due to a shortage of patients. Another randomised controlled trial involving 1210 patients found no clinical or mortality improvement between patients receiving $\mathrm{CP}$ and patients receiving standard care. There was also no evidence of anti-inflammatory properties [48]. Zeng et al found that treatment inhibits viral shedding but doesn't reduce mortality, and late treatment intervention could even be attributed to poorer clinical outcomes [49]. In concordance with previous findings in SARS and MERS, the authors recommend transfusion to be given before day 14 of infection.

\section{Hydroxychloroquine}

Hydroxychloroquine and chloroquine are 4-aminoquinolines. Chloroquine is thought to be a drug that blocks viral entry by inhibiting glycosylation of cell surface receptors, proteolytic processing and endosomal acidification [83]. (Figure 2). It also has immunomodulatory effects and inhibits cytokine production, so could potentially help patients with cytokine storm (Figure 3). Hydroxychloroquine (HCQ), an analogue of chloroquine, has the same antiviral mechanisms but is associated with less drug-drug interactions and adverse effects [84]. Both drugs are used to treat malaria, lupus and rheumatoid arthritis, and are cheap and easy to attain [83].

Hydroxychloroquine is one of the most controversial treatments and is not recommended by the FDA. The WHO discontinued its trial in July 2020 which followed their temporary suspension of the trial in May after a French hospital found the adverse effects of prolonged QTc heart rate intervals caused death due to sudden cardiac arrest [50]. There was a rapid increase in demand of the drug after USA president Donald Trump publicly claimed to use the drug [85]. Initial trials showed both hydroxychloroquine and chloroquine displayed antiviral effects against SARS-CoV-2 in vitro [86]. Strikingly, an open label, non-randomised hydroxychloroquine clinical trial in France found that patients had clear nasopharyngeal viral results in 3-6 days compared to the mean clearance time of 20 days [51].

Other studies show contrasting findings. A randomised, controlled trial of 4716 patients by the Recovery Group found that not only did hydroxychloroquine not provide any benefit, but it also resulted in worse outcomes [52]. The 28-day mortality rate of patients receiving hydroxychloroquine was $27 \%$ compared to $25 \%$ in those receiving standard care. The group receiving the drug was also associated with longer hospitalization and higher progression to invasive mechanical ventilation. A double-blinded, randomised trial was conducted in patients with severe COVID-19 where half were given low dosages of hydroxychloroquine and half were given high dosages of hydroxychloroquine [53]. Worryingly, patients receiving high dosages had a mortality rate of 39\% compared to $15 \%$ receiving low dosages. There was also no evidence of viral clearance. Another randomised, double-blind placebo trial showed that the drug did not prevent postexposure prophylaxis for the illness either [54]. In addition to cardiac side effects, hydroxychloroquine has been reported to cause vomiting and abdominal pain in half of the patients treated [55]. A randomised trial of patients with moderate COVID-19 symptoms conducted in China, found that hydroxychloroquine not only failed to provide benefit, but caused a much higher rate of mainly gastrointestinal adverse effects [56]. Hydroxychloroquine is unlikely to be beneficial in the treatment of COVID-19 but it has been suggested that if given at a low dose with an anti-inflammatory drug it might help mitigate the cytokine storm in critically ill patients [84].

\section{Existing broad-spectrum antiviral drugs}

\section{Lopinavir and ritonavir}

Based on clinical evidence in SARS-CoV and MERS-CoV, the most commonly used antivirals for COVID-19 are lopinavir, ritonavir and ribavirin. Lopinavir/ritonavir (LPVr) combined formulates Kaletra, an FDA approved drug used to treat HIV. Lopinavir inhibits 3-chymotrypsin-like protease (3CL $\left.\mathrm{L}^{\mathrm{pro}}\right)$ which disrupts viral replication and RNA release from host cells [87] (Figure 2). Ritonavir is a human CYP3A4 enzyme inhibitor. In addition, lopinavir efficacy was found to be inferior to remdesivir and interferon- $\beta$ [88]. Randomised, controlled 
clinical trials of COVID-19 patients found that LPVr was not associated with clinical improvement $[57,58]$. Furthermore, up to $50 \%$ of patients could experience adverse effects including gastrointestinal problems and hepatoxicity [57].

\section{Interferon}

Interferons (IFNs) are cytokines discovered to have antiviral properties in 1957 and have since been approved for clinical use by the FDA [89]. They are widely available to treat hepatitis, leukaemia and carcinoma [90]. Human cells naturally produce type I interferons, IFN- $\alpha$ and IFN- $\beta$, in response to viral infections. Of these, IFN- $\beta$ is the most potent [90]. They are crucial in inhibiting viral replication and can also activate the transcription of hundreds of genes which produce virus controlling proteins [91] (Figure 3).

IFN- $\beta$ la combined with Lopinavir/Ritonavir was previously approved for international trialling by WHO. A randomised clinical trial of 81 patients found that IFN- $\beta$ la decreased the 28-day mortality rate from $43.6 \%$ to $19 \%$, although it did not change time taken to reach clinical response [59]. Further support of this treatment was found in a recent randomised, double-blind, placebo-controlled trial which found patients receiving nebulised IFN- $\beta$ la were twice as likely to recover than the standard group (44\% vs $22 \%$ ) [60]. Similarly, IFN- $\beta$ lb is also thought to be beneficial. The results of a randomised clinical trial in 66 patients showed that it caused a significantly shorter time for clinical improvement and it reduced 28-day mortality from $18.8 \%$ to $6 \%$ [61]. However, an open-label, randomised, phase 2 clinical trial carried out in 127 patients suggested that although patients with moderate symptoms had a significantly better clinical and virologic response, it is unlikely to benefit patients with severe symptoms [62].

\section{Corticosteroids}

Corticosteroids are hormones naturally produced by the adrenal cortex, principally in the form of glucocorticoids and mineralocorticoids. They have widespread effects on the human body including metabolic regulation and reducing vasodilation [92]. Glucocorticoids bind to glucocorticoid receptors (GR) on the cell cytoplasm and regulates gene expression [93]. This can produce anti-inflammatory and immunosuppressant factors which is useful pharmacologically. Synthetic glucocorticoids include betamethasone which treats asthma, and prednisolone which treats COPD and rheumatoid arthritis.

Due to its controversy, corticosteroids were not previously recommended by WHO to treat COVID-19. However, on 2 September 2020 it was approved for the treatment of patients in critical condition [94]. Theoretically, corticosteroids should inhibit the symptoms of a "cytokine storm" which only presents in patients classified as severe $[63,64,95]$ (Figure 3). Clinical studies reported that around 20\%-50\% of observed COVID-19 patients received this treatment. In an observational study, Zhang et al suggested that corticosteroids could possibly produce early clinical benefits in COVID-19 [36]. The effectiveness of corticosteroid therapy was contested by Zhou et al, who thought that high dose corticosteroids could have contributed to poor clinical outcomes in a cohort study [65]. Recent findings have reinstated corticosteroids as an important drug in this pandemic. In contrast to most outcomes of corticosteroid trials [66], the steroid dexamethasone seems very promising. Furthermore, a recent review suggested that hydrocortisones has a similar effectiveness [67]. A trial carried out in hospitalised patients by the Recovery Collaborative Group found dexamethasone reduced the mortality rate for patients on ventilators from $41.4 \%$ to $29.3 \%$, and from $26.2 \%$ to $23.3 \%$ for patients needing oxygen [68]. However, there was no benefit in its use for patients with moderate symptoms. For patients who were not receiving any respiratory support, patients who received dexamethasone had a mortality rate of $17.8 \%$, compared to a $14 \%$ mortality in the control group. Prolonged corticosteroid treatment may be effective in saving lives of severe patients who develop ARDS and multiple organ failure, but short therapy is suggested to increase death, so cannot be thought as an effective cure [96].

\section{Drugs targeting the cytokine storm}

The most critically ill COVID-19 patients develop a massive immune response, resulting in a cytokine storm. This causes ARDS and multi-organ failure. Moderation of immune mediators such as Janus Kinase (JAK), bruton tyrosine kinase (BTK) and interleukins (IL) are crucial in saving patient lives (Figure 3). JAK inhibitors include baricitinib and ruxolitnib. A clinical trial found patients treated with baricitinib achieved significantly greater clinical improvements. After 2 weeks, $58 \%$ of the treated patients were discharged compared to $8 \%$ of the control group [69]. It also significantly reduced IL-1 $\beta$, IL-6, and TNF- $\alpha$ plasma concentrations [70]. Patients given ruxolitinib in a randomised, controlled trial displayed significantly decreased levels of cytokines and numerically faster clinical improvement [71]. Acalabrutinib, a BTK inhibitor, was found to improve symptoms of severe patients [72]. In a cohort study the IL-1 receptor antagonist Anakinra was found to greatly re- 
duce the need for invasive mechanical ventilation and decrease mortality in a cohort study from $73 \%$ in the historical group to $25 \%$ in the treatment group [73]. This result has been supported by other similar studies [74]. The therapeutic effects of these cytokine storm inhibiting drugs seem favourable, but more high quality, randomised controlled trials are needed to fully assess its affects.

\section{Development of novel specific treatment agents}

\section{Monoclonal and polyclonal antibodies}

Monoclonal antibodies are produced from immunized animals, antibody human phage libraries and memory B cells of recovered patients [90]. Compared to convalescent plasma treatment, monoclonal antibodies are an alternative strategy which has higher efficacy, is able to be expressed in larger quantities and reduces the risk of antibody dependent enhancement [97].

Tocilizumab is a recombinant, anti-human IL-6R monoclonal antibody that inhibits hyperinflammation in patients with COVID-19. It is currently most well known in treating rheumatoid arthritis, another inflammatory immune disease. A randomised, double-blind, placebo-controlled trial in 389 moderate to severe patients found that tocilizumab improved the combined progression to either mechanical ventilation or death (12\% vs 19.3\%). However, it did not improve survival alone [75]. Another randomised trial also found that there was no improvement in 28-day mortality in moderate and severe cases [76]. In fact, in more critical cases, tocilizumab may lead to worse outcomes. A randomised, open label trial of severe or critical COVID-19 patients found death at 15 days increased from 3\% in the standard care group to $17 \%$ in the patients receiving treatment and was linked to a higher occurrence of adverse events [77]. The trial was not completed due to the large number of deaths.

REGN-COV2 is a monoclonal antibody cocktail that target the RBD of the S1 or the S2 segment of spike proteins, thus interfering with entry into the host cell. Recent results of a double- blind, randomised controlled trial of REGN-COV2 show a reduced viral load especially in patient whose immune response had not yet been initiated [78]. Some other potential monoclonal antibodies effective against SARS-CoV-2 include B38, H4 and CR3022 [98,99].

\section{DISCUSSION}

In this rapid review, we summarise the literature on COVID-19 treatments. There is not yet a completely effective cure for COVID-19. This review found no certain evidence of any single therapy to significantly improve clinical outcomes. Of the 40 studies included, 18 reported clinical improvement while 17 reported no significant result and 5 reported a worsening of clinical progression. Most of the studies reporting clinical improvement are observational and have a limited sample size. Many of these studies report that although the therapy studied was effective in improving patient recovery time and symptoms of mild disease, it is not effective in preventing mortality rates of severe patients. In contrast, many randomised controlled trials report no significant improvements or even worsened outcomes.

Timing of administration is crucial in drug efficacy. In accordance with the SARS-CoV-2 peak replication time and the patient's primary immune response, therapies appear to be most beneficial when given before 14 days of infection $[1,49,100,101]$. Broad-spectrum antiviral treatments could benefit patients with mild symptoms in the early stages of infection but are ineffective in treating severe disease patients. Remdesivir, convalescent plasma and interferon were found to reduce viral load and improve patient recovery time but failed to prevent mortality. Conversely, dexamethasone and hydrocortisones have been proven to save lives in severe patients but are not effective in mild cases. Other drugs like hydroxychloroquine do not seem to be effective in either mild or severe patients.

There is evidence that remdesivir can improve recovery time in COVID-19 patients and reduce the mortality rate from $11.9 \%$ to $6.7 \%$ [42]. Nonetheless, other randomised controlled trials suggest that any benefit is not clinically significant $[41,43]$. These results are consistent with in vitro and animal studies. Remdesivir is highly effective in reducing replication of SARS-CoV-2 in human cell lines [86]. However, in rhesus macaques, although it reduced clinical disease and lung damage, there was no reduction of virus replication in the upper respiratory tract [102]. Current evidence from previous coronaviruses do not suggest added benefit of the drug. In initial studies, remdesivir was found to have prophylactic and therapeutic effects against SARS- and MERS$\mathrm{CoV}$ in human airway epithelial cells and in animals, as well as having antiviral properties against HCoV-299E and HCoV-OC43 [103]. However when used therapeutically in MERS patients, it was unable to prevent mortality or loss of pulmonary function [88]. 
Convalescent plasma therapy was found to be effective in reducing viral clearance in COVID-19 patients $[47,49]$. However, there is limited effect on the clinical outcomes of patients $[47,48]$. Efficacy of CP was initially supported in trials involving SARS and was reported to be effective in decreasing mortality rate in several studies [104]. In deteriorating SARS patients, switching to CP therapy was associated with better outcomes than continuing high dose methylprednisolone [105]. Studies on MERS better reflect the outcomes for COVID-19 patients. Initial experiments on immune camel serum was found to be able to diminish weight loss and lung histological changes, and improve virus clearance in mice [106]. However, it was found that antibody titres collected from recovered patients were too low in the plasma to covey any therapeutic effect [107]. Thus in 2014, the WHO's stance on CP changed from being the most promising nearterm MERS therapy to be only regarded as investigational [90]. In concordance with findings in SARS and MERS, it is recommend transfusion to be given early, before day 14 of infection, for greatest therapeutic effect in COVID-19 patients [49].

A treatment suggesting very limited potential is hydroxychloroquine. The drug was associated with a higher mortality of $27 \%$ compared to $25 \%$ in the control, as well as longer hospitalisation [52]. There are also several worrying side effects including cardiac symptoms. In previous coronaviruses, chloroquine was shown to inhibit SARS-CoV, MERS-CoV and HCoV-229E_in vitro $[108,109]$. Hydroxychloroquine was similarly effective in SARS, suggesting it to be a potential pharmacological agent for coronaviruses [84]. However, the effects of chloroquine/ hydroxychloroquine were never fully explored in vivo [110] and the discrepancy with COVID-19 highlights the need for vigorous drug testing upon translation from in vitro studies to patients.

Broad spectrum antivirals LPVr are common treatments for COVID-19 patients. However, it is unlikely to provide any clinical improvement $[57,58]$. Lopinavir inhibits SARS-CoV-2 in vitro but it was recently found that ritonavir did not [87]. Studies in SARS and MERS provide further evidence of their limitations. Although LPVr inhibited the replication of SARS-CoV, it was not effective in MERS-CoV [111]. Other antivirals such as Ribavirin, a nucleoside analogue that inhibits viral RdRp [112] is similarly unlikely to provide clinical value. In vitro it was found that it could only inhibit SARS-CoV at very high levels which is difficult to achieve clinically [113] and has no benefit in SARS and MERS patients [83]. Although unlikely to be effective alone, broad spectrum antivirals may play a role in conjunction with other therapies.

Several randomised controlled trials demonstrate the benefits of IFN- $\beta$. The drug was shown to improve time for clinical improvement and recovery, and also decrease 28-day mortality from $43.6 \%$ to 19\% [59]. Evidence from previous years show IFN is able to inhibit SARS- and MERS-CoV replication both in vitro and in animals [37] and had maximum effect used in combination with the broad spectrum antivirals, lopinavir/ritonavir and ribavirin [112]. A clinical trial of IFN- $\alpha 2$ and ribavirin in MERS patients showed improvement in 14-days survival but not 28 -day survival. Significantly, IFN- $\beta$ la resulted in a mortality rate of $64 \%$ compared to $85 \%$ in IFN- $\alpha 2 \mathrm{a}[90]$.

It is suggested that corticosteroids such as dexamethasone are vital in preventing mortality in patients with severe COVID-19 [68]. Current evidence reported from SARS and MERS suggest varied benefit. A non-randomised and uncontrolled trial showed that $89 \%$ of 107 patients who received high dose methylprednisolone recovered from the disease [114]. In contrast, a randomized, double-blinded, placebo-controlled trial showed that corticosteroids caused an increase in patient viral load and decrease in viral clearance [28]. Similarly in MERS, a study concluded that corticosteroids not only had no effect in preventing ARDS and pulmonary fibrosis, it was also associated with osteonecrosis, delirium and aspergillosis [90]. Further contradiction arises in a 2020 randomised trial of ARDS patients which found that methylprednisolone was associated with a significant increase in death [115].

There is promise in new cytokine storm targeting drugs like JAK and BTK inhibitors, but further investigation is required to discern its value for treating critically ill. Previously, monoclonal antibodies were shown to have neutralizing effects in vitro, in mice and in rhesus macaques for SARS and MERS $[90,116]$. However, there is no evidence that tocilizumab is effective in treating COVID-19 patients and REGN-COV2 requires further investigation to fully understand its effects.

Future prospects of the pandemic could depend mainly on the development of novel therapies like monoclonal antibodies and prevention through effective and widespread vaccination which will be effective against mutated strains. Meanwhile, to halt the spread of the virus, social distancing and good hygiene practises such as handwashing and face coverings or masks are essential [117].

As of 8 March 2021, there are 308 candidate COVID-19 vaccines of which 16 have entered phase 3 trial, and 4 have entered phase 4 [118]. There are several vaccines currently in use. The WHO has issued emergency use 
listings (EULs) for Pfizer-BioNtech COVID-19 vaccine and AstraZeneca/Oxford COVID-19 vaccine. The FDA have further approved of the Pfizer-BioNtech, Moderna and Janssen vaccines. ChAdOxl nCoV-19, developed by the University of Oxford and AstraZeneca is in use in the UK. It is a chimpanzee adenovirus-vectored vaccine. Results from phases $1 / 2$ and $2 / 3$ trials show neutralising antibody responses in $>99 \%$ of participants by 14 days, and potent cellular and humoral immunogenicity in all participants after a second dose $[119,120]]$. Interim results also show up to $71.2 \%$ efficacy from the phase 3 Brazil trial [121]. BNT162b2 developed by Pfizer and Biotech, is a mRNA vaccine. It is also being rolled out in the UK, as well as the US and following phase 3 trial is reported to be 95\% effective [122]. Prospective studies of ChAdOxl nCoV-19 and BNT162b2 from real world data in the UK confirms their protective effect against hospitalisation $[123,124]$. Another mRNA vaccine, mRNA-1273, developed by Moderna is currently rolled out in the US, and is reported to be $94.5 \%$ effective on preventing COVID-19 [125].

Other vaccines include the CoronaVac (formerly PiCoVacc) which was found in phase 1 and 2 trials to be safe in inducing neutralizing antibodies with a $97.4 \%$ seroconversion rate after 28 days [126]. Other promising vaccines are the adenovirus vectored vaccines. Phase 1 and 2 trials on Ad5 by CanSino Biologics show its safety in causing a $97 \%$ antibody seroconversion rate in participants by 28 days [127]. The Janssen vaccine (Ad26) by Johnson\& Johnson is similarly favourable in causing neutralising antibodies in over $90 \%$ of participants [128].

This review presents a current overview of COVID-19 therapies and links their development to their efficacy in previous coronaviruses for a more comprehensive picture of their likely trajectory. Future directions of the pandemic are considered by discussing initial studies of novel therapies and vaccines. There are also a number of limitations. First, due to the massive amount and fast pace of publications regarding COVID-19, new findings are constantly changing the treatment landscape. We included some preliminary results of ongoing studies in which not all data was available or presented. Second, due to more limited evidence, we were unable to include all identified COVID-19 therapies in this review such as oseltamivir and colchicine. Third, in observational and retrospective studies included, the duration and dose of therapy were not standardised and may be subject to bias. Fourth, the literature was limited to studies published in English and was searched for in only two databases. The search and screening process was not screened twice.

\section{CONCLUSION}

While the pandemic continues to spread worldwide, there is urgent need to understand the benefits and risks of each treatment. Living drug treatment systematic reviews which updates when new evidence becomes available can be followed [129]. Currently there is no single effective treatment against COVID-19. A combination of therapies administered at different stages of infection seems to provide the best outcomes in patients. As most clinical trials are carried out in severe patients, there is a need for more high quality randomised controlled trials, especially of patients in earlier stages of infection. An effective and safe vaccine distributed worldwide will be a turning point in resolving the COVID-19 pandemic.

Acknowledgements: UNCOVER (Usher Network for COVID-19 Evidence Reviews) authors that contributed to this review are: Ms Marshall Dozier, Dr Ruth McQuillan, Prof Harish Nair, Ms Emilie McSwiggan, Prof Gerry Fowkes.

Funding: ET is funded by a CRUK Career Development Fellowship (C31250/A22804). UNCOVER is supported by Wellcome Trust ISSF3 and Data Driven Innovation funding.

Authorship contributions: YD conducted the literature search. YD and AS screened the search results and extracted the data. YD prepared the first draft with important contributions from ET. All authors contributed to the conceptualization and revisions of the paper.

Competing interests: Harry Campbell is the Co-Editor in Chief of the Journal of Global Health. To ensure that any possible conflict of interest relevant to the journal has been addressed, this article was reviewed according to best practice guidelines of international editorial organisations. The authors completed the ICMJE Unified Competing Interest form (available upon request from the corresponding author) and declare no further conflicts of interest.

Additional material

Online Supplementary Document 
1 Cheng Y, Wong R, Soo YOY, Wong WS, Lee CK, Ng MHL, et al. Use of convalescent plasma therapy in SARS patients in Hong Kong. Eur J Clin Microbiol Infect Dis. 2005;24:44-6. Medline:15616839 doi:10.1007/s10096-004-1271-9

2 WHO. WHO Coronavirus Disease (COVID-19) Dashboard. 2021. Available: https://covid19.who.int/. Accessed: 8 March 2021.

3 Nicola M, Alsafi Z, Sohrabi C, Kerwan A, Al-Jabir A, Iosifidis C, et al. The socio-economic implications of the coronavirus pandemic (COVID-19): A review. Int J Surg. 2020;78:185-93. Medline:32305533 doi:10.1016/j.jjsu.2020.04.018

4 Thunström L, Newbold SC, Finnoff D, Ashworth M, Shogren JF. The Benefits and Costs of Using Social Distancing to Flatten the Curve for COVID-19. J Benefit Cost Anal. 2020;11:179-195. doi:10.1017/bca.2020.12

$5 \mathrm{Xu}$ S, Li Y. Beware of the second wave of COVID-19. Lancet. 2020;395:1321-2. Medline:32277876 doi:10.1016/S01406736(20)30845-X

6 Pfefferle S, Oppong S, Drexler JF, Gloza-Rausch F, Ipsen A, Seebens A, et al. Distant relatives of severe acute respiratory syndrome coronavirus and close relatives of human coronavirus 229E in bats, Ghana. Emerg Infect Dis. 2009;15:1377-84. Medline:19788804 doi:10.3201/eid1509.090224

7 Cecil RLF, Goldman L, Schafer AL. Goldman's Cecil Medicine, Expert Consult Premium Edition Elsevier Health Sciences; 2012.

8 Xia S, Xu W, Wang Q, Wang C, Hua C, Li W, et al. Peptide-based membrane fusion inhibitors targeting HCOV-229E spike protein HR1 and HR2 domains. Int J Mol Sci. 2018;19:487. Medline:29415501 doi:10.3390/ijms19020487

9 Forni D, Cagliani R, Clerici M, Sironi M. Molecular Evolution of Human Coronavirus Genomes. Trends Microbiol. 2017;;25:3548. Medline:27743750 doi:10.1016/j.tim.2016.09.001

10 Walsh EE, Shin JH, Falsey AR. Clinical impact of human coronaviruses 229E and OC43 infection in diverse adult populations. J Infect Dis. 2013;208:1634-42. Medline:23922367 doi:10.1093/infdis/jit393

11 Hui DSC, Chan MCH, Wu AK, Ng PC. Severe acute respiratory syndrome (SARS): Epidemiology and clinical features. Postgrad Med J. 2004;80:373-81. Medline:15254300 doi:10.1136/pgmj.2004.020263

12 Drosten C, Günther S, Preiser W, van der Werf S, Brodt H-R, Becker S, et al. Identification of a Novel Coronavirus in Patients with Severe Acute Respiratory Syndrome. N Engl J Med. 2003;348:1967-76. Medline:12690091 doi:10.1056/NEJMoa030747

13 World Health Organization. Severe acute respiratory syndrome (SARS). 2015. Available: https://www.who.int/health-topics/ severe-acute-respiratory-syndrome\#tab=tab_1. Accessed: 29 May 2020.

14 Lee N, Hui D, Wu A, Chan P, Cameron P, Joynt G, et al. A major outbreak of severe acute respiratory syndrome in Hong Kong. N Engl J Med. 2003;348:1986-94. Medline:12682352 doi:10.1056/NEJMoa030685

15 Gaunt ER, Hardie A, Claas ECJ, Simmonds P, Templeton KE. Epidemiology and clinical presentations of the four human coronaviruses 229E, HKU1, NL63, and OC43 detected over 3 years using a novel multiplex real-time PCR method. J Clin Microbiol. 2010;48:2940-7. Medline:20554810 doi:10.1128/JCM.00636-10

16 Kanwar A, Selvaraju S, Esper F. Human coronavirus-HKU1 infection among adults in Cleveland, Ohio. Open Forum Infect Dis. 2017:4:ofx052. Medline:28616442 doi:10.1093/ofid/ofx052

17 Lau SKP, Woo PCY, Yip CCY, Tse H, Tsoi HW, Cheng VCC, et al. Coronavirus HKU1 and other coronavirus infections in Hong Kong. J Clin Microbiol. 2006;44:2063-71. Medline:16757599 doi:10.1128/JCM.02614-05

18 Chafekar A, Fielding BC. MERS-CoV: Understanding the latest human coronavirus threat. MDPI AG; 2018.

19 Mackay IM, Arden KE. MERS coronavirus: Diagnostics, epidemiology and transmission. Virol J. 2015;12:222. Medline:26695637 doi:10.1186/s12985-015-0439-5

20 CDC. MERS Clinical Features.2020. Available: https://www.cdc.gov/coronavirus/mers/clinical-features.html. Accessed: 17 July 2020.

21 Alraddadi BM, Watson JT, Almarashi A, Abedi GR, Turkistani A, Sadran M, et al. Risk factors for primary middle east respiratory syndrome coronavirus illness in humans, Saudi Arabia, 2014. Emerg Infect Dis. 2016;22:49-55. Medline:26692185 doi:10.3201/eid2201.151340

22 Wang D, Hu B, Hu C, Zhu F, Liu X, Zhang J, et al. Clinical Characteristics of 138 Hospitalized Patients with 2019 Novel Coronavirus-Infected Pneumonia in Wuhan, China. JAMA. 2020;323:1061-9. Medline:32031570 doi:10.1001/jama.2020.1585

23 Ge H, Wang X, Yuan X, Xiao G, Wang C, Deng T, et al. The epidemiology and clinical information about COVID-19. Eur J Clin Microbiol Infect Dis. 2020;39:1011-9. Medline:32291542 doi:10.1007/s10096-020-03874-z

24 Lu CW, Liu XF, Jia ZF. 2019-nCoV transmission through the ocular surface must not be ignored. Lancet. 2020;395:e39. Medline:32035510 doi:10.1016/S0140-6736(20)30313-5

25 WHO. Transmission of SARS-CoV-2: implications for infection prevention precautions. Scientific brief, 09 July 2020. 2020. Available: https://www.who.int/news-room/commentaries/detail/transmission-of-sars-cov-2-implications-for-infection-prevention-precautions. Accessed: 28 May 2020.

26 Guan WJ, Liang WH, Zhao Y, Liang HR, Chen ZS, Li YM, et al. Comorbidity and its impact on 1590 patients with COVID-19 in China: A Nationwide Analysis. Eur Respir J. 2020;55:2000547. Medline:32217650 doi:10.1183/13993003.00547-2020

27 World Health Organization. Middle East respiratory syndrome coronavirus (MERS-CoV). 2020. Available: https://www.who. int/health-topics/middle-east-respiratory-syndrome-coronavirus-mers\#tab=tab_1. Accessed: 29 May 2020.

28 Stockman LJ, Bellamy R, Garner P. SARS: Systematic review of treatment effects. PLoS Med. 2006;3:1525-31. Medline:16968120 doi:10.1371/journal.pmed.0030343

29 Cameron MJ, Ran L, Xu L, Danesh A, Bermejo-Martin JF, Cameron CM, et al. Interferon-Mediated Immunopathological Events Are Associated with Atypical Innate and Adaptive Immune Responses in Patients with Severe Acute Respiratory Syndrome. J Virol. 2007;81:8692-706. Medline:17537853 doi:10.1128/JVI.00527-07

30 Ware LB, Matthay MA. The acute respiratory distress syndrome. N Engl J Med. 2000;342:1334-49. Medline:10793167 doi:10.1056/NEJM200005043421806 
32 CDC. Clinical Guidance for Management of Patients with Confirmed Coronavirus Disease (COVID-19) 2020. Available: https:// www.cdc.gov/coronavirus/2019-ncov/hcp/clinical-guidance-management-patients.html. Accessed: 26 August 2020.

33 Grasselli G, Pesenti A, Cecconi M. Critical Care Utilization for the COVID-19 Outbreak in Lombardy, Italy. JAMA. 2020;323:1545-6. Medline:32167538 doi:10.1001/jama.2020.4031

34 Johns Hopkins University \& Medicine. Mortality Analyses - Johns Hopkins Coronavirus Resource Center. 2021. Available: https://coronavirus.jhu.edu/data/mortality. Accessed: 4 April 2020.

35 Ludvigsson JF. Systematic review of COVID-19 in children shows milder cases and a better prognosis than adults. Acta Paediatr. 2020;109:1088-95. Medline:32202343 doi:10.1111/apa.15270

36 Zhang G, Hu C, Luo L, Fang F, Chen Y, Li J, et al. Clinical features and short-term outcomes of 221 patients with COVID-19 in Wuhan, China. J Clin Virol. 2020;127:104364. Medline:32311650 doi:10.1016/j.jcv.2020.104364

37 Zumla A, Chan JFW, Azhar EI, Hui DSC, Yuen KY. Coronaviruses-drug discovery and therapeutic options. Nature. 2016;15:32747. Medline:26868298

38 World Health Organization. Solidarity clinical trial for COVID-19 treatments.2020. Available: https://www.who.int/emergencies/ diseases/novel-coronavirus-2019/global-research-on-novel-coronavirus-2019-ncov/solidarity-clinical-trial-for-covid-19-treatments. Accessed: 11 July 2020.

39 Nuffield Department of Population Health. RECOVERY Trial. 2020. Available: https://www.recoverytrial.net/. Accessed: 28 August 2020

40 Grein J, Ohmagari N, Shin D, Diaz G, Asperges E, Castagna A, et al. Compassionate Use of Remdesivir for Patients with Severe COVID-19. N Engl J Med. 2020;382:2327-36. Medline:32275812 doi:10.1056/NEJMoa2007016

41 Wang Y, Zhang D, Du G, Du R, Zhao J, Jin Y, et al. Remdesivir in adults with severe COVID-19: a randomised, double-blind, placebo-controlled, multicentre trial. Lancet. 2020;395:1569-78. Medline:32423584 doi:10.1016/S0140-6736(20)31022-9

42 Beigel JH, Tomashek KM, Dodd LE, Mehta AK, Zingman BS, Kalil AC, et al. Remdesivir for the Treatment of COVID-19 - Final Report. N Engl J Med. 2020;383:1813-26. Medline:32445440 doi:10.1056/NEJMoa2007764

43 Spinner CD, Gottlieb RL, Criner GJ, Arribas López JR, Cattelan AM, Soriano Viladomiu A, et al. Effect of Remdesivir vs Standard Care on Clinical Status at 11 Days in Patients with Moderate COVID-19: A Randomized Clinical Trial. JAMA. 2020;324:104857. Medline:32821939 doi:10.1001/jama.2020.16349

44 Salazar E, Perez K, Madiha A, Chen J. Treatment of COVID-19 Patients with Convalescent Plasma Eric. Am J Pathol. 2020;190:1680-90. Medline:32473109 doi:10.1016/j.ajpath.2020.05.014

45 Abolghasemi H, Eshghi P, Cheraghali AM, Imani Fooladi AA, Bolouki Moghaddam F, Imanizadeh S, et al. Clinical efficacy of convalescent plasma for treatment of COVID-19 infections: Results of a multicenter clinical study. Transfus Apheresis Sci. 2020;59:102875. Medline:32694043 doi:10.1016/j.transci.2020.102875

46 Alsharidah S, Ayed M, Ameen RM, Alhuraish F, Rouheldeen NA, Alshammari FR, et al. COVID-19 convalescent plasma treatment of moderate and severe cases of SARS-CoV-2 infection: A multicenter interventional study. Int J Infect Dis. 2021;103:43946. Medline:33285283 doi:10.1016/j.ijid.2020.11.198

47 Li L, Zhang W, Hu Y, Tong X, Zheng S, Yang J, et al. Effect of Convalescent Plasma Therapy on Time to Clinical Improvement in Patients With Severe and Life-threatening COVID-19: A Randomized Clinical Trial. JAMA. 2020;324:460-70. Medline:32492084 doi:10.1001/jama.2020.10044

48 Agarwal A, Mukherjee A, Kumar G, Chatterjee P, Bhatnagar T, Malhotra P. Convalescent plasma in the management of moderate COVID-19 in adults in India: open label phase II multicentre randomised controlled trial (PLACID Trial). BMJ. 2020;371:m3939. Medline:33093056 doi:10.1136/bmj.m3939

49 Zeng Q-L, Yu Z-J, Gou J-J, Li G-M, Ma S-H, Zhang G-F, et al. Effect of Convalescent Plasma Therapy on Viral Shedding and Survival in Patients With Coronavirus Disease 2019. J Infect Dis. 2020;222: 38-43. Medline:32348485 doi:10.1093/infdis/jiaa228

50 Mahévas M, Tran VT, Roumier M, Chabrol A, Paule R, Guillaud C, et al. Clinical efficacy of hydroxychloroquine in patients with COVID-19 pneumonia who require oxygen: Observational comparative study using routine care data. BMJ. 2020;369:m1844. Medline:32409486 doi:10.1136/bmj.m1844

51 Gautret P, Lagier J-C, Parola P, Hoang VT, Meddeb L, Mailhe M, et al. Hydroxychloroquine and azithromycin as a treatment of COVID-19: results of an open-label non-randomized clinical trial. Int J Antimicrob Agents. 2020;56:105949. Medline:32205204 doi:10.1016/j.ijantimicag.2020.105949

52 Horby P, Mafham M, Linsell L, Bell JL, Staplin N, Emberson JR, et al. Effect of Hydroxychloroquine in Hospitalized Patients with COVID-19. N Engl J Med. 2020;383:2030-40. Medline:33031652 doi:10.1056/NEJMoa2022926

53 Borba MGS, Val FFA, Sampaio VS, Alexandre MAA, Melo GC, Brito M, et al. Effect of High vs Low Doses of Chloroquine Diphosphate as Adjunctive Therapy for Patients Hospitalized With Severe Acute Respiratory Syndrome Coronavirus 2 (SARSCoV-2) Infection: A Randomized Clinical Trial. JAMA Netw Open. 2020;3:208857. Medline:32330277 doi:10.1001/jamanetworkopen.2020.8857

54 Boulware DR, Pullen MF, Bangdiwala AS, Pastick KA, Lofgren SM, Okafor EC, et al. A Randomized Trial of Hydroxychloroquine as Postexposure Prophylaxis for COVID-19. N Engl J Med. 2020;383:517-25. Medline:32492293 doi:10.1056/NEJMoa2016638

55 Huang M, Tang T, Pang P, Li M, Ma R, Lu J, et al. Treating COVID-19 with Chloroquine. J Mol Cell Biol. 2020;12:322-5. Medline:32236562 doi:10.1093/jmcb/mjaa014

56 Tang W, Cao Z, Han M, Wang Z, Chen J, Sun W, et al. Hydroxychloroquine in patients with mainly mild to moderate coronavirus disease 2019: open label, randomised controlled trial. BMJ. 2020;369:m1849. Medline:32409561 doi:10.1136/bmj.m1849 
57 Cao B, Wang Y, Wen D, Liu W, Wang J, Fan G, et al. A Trial of Lopinavir-Ritonavir in Adults Hospitalized with Severe COVID-19. N Engl J Med. 2020;382:1787-99. Medline:32187464 doi:10.1056/NEJMoa2001282

58 Horby PW, Mafham M, Bell JL, Linsell L, Staplin N, Emberson J, et al. Lopinavir-ritonavir in patients admitted to hospital with COVID-19 (RECOVERY): a randomised, controlled, open-label, platform trial. Lancet. 2020;396:1345-52. doi:10.1016/ S0140-6736(20)32013-4

59 Davoudi-Monfared E, Rahmani H, Khalili H, Hajiabdolbaghi M, Salehi M, Abbasian L, et al. A randomized clinical trial of the efficacy and safety of interferon $\beta$-la in treatment of severe COVID-19. Antimicrob Agents Chemother. 2020;64:e01061-20. Medline:32661006 doi:10.1128/AAC.01061-20

60 Monk PD, Marsden RJ, Tear VJ, Brookes J, Batten TN, Mankowski M, et al. Safety and efficacy of inhaled nebulised interferon beta-la (SNG001) for treatment of SARS-CoV-2 infection: a randomised, double-blind, placebo-controlled, phase 2 trial. Lancet Respir Med. 2021;9:196-206. Medline:33189161 doi:10.1016/S2213-2600(20)30511-7

61 Rahmani H, Davoudi-Monfared E, Nourian A, Khalili H, Hajizadeh N, Jalalabadi NZ, et al. Interferon $\beta$-1b in treatment of severe COVID-19: A randomized clinical trial. Int Immunopharmacol. 2020;88:106903. Medline:32862111 doi:10.1016/j. intimp.2020.106903

62 Hung IF-N, Lung K-C, Tso EY-K, Liu R, Chung TW-H, Chu M-Y, et al. Triple combination of interferon beta-1b, lopinavir-ritonavir, and ribavirin in the treatment of patients admitted to hospital with COVID-19: an open-label, randomised, phase 2 trial. Lancet. 2020;395:1695-704. Medline:32401715 doi:10.1016/S0140-6736(20)31042-4

63 Liu Y, Sun W, Li J, Chen L, Wang Y, Zhang L, et al. Clinical features and progression of acute respiratory distress syndrome in coronavirus disease 2019. medRxiv. 2020. doi:10.1101/2020.02.17.20024166

64 Liu T, Zhang J, Yang Y, Zhang L, Ma H, Li Z, et al. The Potential Role of IL-6 in Monitoring Coronavirus Disease 2019. SSRN Electronic Journal. 2020;2019. doi:10.2139/ssm.3548761

65 Zhou F, Yu T, Du R, Fan G, Liu Y, Liu Z, et al. Clinical course and risk factors for mortality of adult inpatients with COVID-19 in Wuhan, China: a retrospective cohort study. Lancet. 2020;395:1054-62. Medline:32171076 doi:10.1016/S01406736(20)30566-3

66 Tobaiqy M, Qashqary M, Al-Dahery S, Mujallad A, Hershan AA, Kamal MA, et al. Therapeutic management of patients with COVID-19: a systematic review. Infection Prevention in Practice. 2020;2:100061. doi:10.1016/j.infpip.2020.100061

67 Sterne JAC, Murthy S, Diaz JV, Slutsky AS, Villar J, Angus DC, et al. Association Between Administration of Systemic Corticosteroids and Mortality Among Critically Ill Patients With COVID-19: A Meta-analysis. JAMA. 2020;324:1330-41. Medline:32876694 doi:10.1001/jama.2020.17023

68 Group TRC. Dexamethasone in Hospitalized Patients with COVID-19. N Engl J Med. 2021;384:693-704. Medline:32678530 doi:10.1056/NEJMoa2021436

69 Cantini F, Niccoli L, Matarrese D, Nicastri E, Stobbione P, Goletti D. Baricitinib therapy in COVID-19: A pilot study on safety and clinical impact. W.B. Saunders Ltd; 2020. p. 318-56

70 Bronte V, Ugel S, Tinazzi E, Vella A, de Sanctis F, Canè S, et al. Baricitinib restrains the immune dysregulation in patients with severe COVID-19. J Clin Invest. 2020;130:6409-16. Medline:32809969 doi:10.1172/JCI141772

71 Cao Y, Wei J, Zou L, Jiang T, Wang G, Chen L, et al. Ruxolitinib in treatment of severe coronavirus disease 2019 (COVID-19): A multicenter, single-blind, randomized controlled trial. J Allergy Clin Immunol. 2020;146:137-46.e3. Medline:32470486 doi:10.1016/j.jaci.2020.05.019

72 Roschewski M, Lionakis MS, Sharman JP, Roswarski J, Goy A, Monticelli MA, et al. Inhibition of Bruton tyrosine kinase in patients with severe COVID-19. Sci Immunol. 2020;5:eabd0110. Medline:32503877 doi:10.1126/sciimmunol.abd0110

73 Huet T, Beaussier H, Voisin O, Jouveshomme S, Dauriat G, Lazareth I, et al. Anakinra for severe forms of COVID-19: a cohort study. Lancet Rheumatol. 2020;2:e393-e400. Medline:32835245 doi:10.1016/S2665-9913(20)30164-8

74 Balkhair A, Al-Zakwani I, Al Busaidi M, Al-Khirbash A, Al Mubaihsi S, Bataher H, et al. Anakinra in hospitalized patients with severe COVID-19 pneumonia requiring oxygen therapy: Results of a prospective, open-label, interventional study. Int J Infect Dis. 2021;103:288-96. Medline:33217576 doi:10.1016/j.ijid.2020.11.149

75 Salama C, Han J, Yau L, Reiss WG, Kramer B, Neidhart JD, et al. Tocilizumab in Patients Hospitalized with COVID-19 Pneumonia. N Engl J Med. 2021;384:20-30. Medline:33332779 doi:10.1056/NEJMoa2030340

76 Hermine O, Mariette X, Tharaux PL, Resche-Rigon M, Porcher R, Ravaud P. Effect of Tocilizumab vs Usual Care in Adults Hospitalized with COVID-19 and Moderate or Severe Pneumonia: A Randomized Clinical Trial. JAMA Intern Med. 2021;181:3240. Medline:33080017 doi:10.1001/jamainternmed.2020.6820

77 Veiga VC, Prats JAGG, Farias DLC, Rosa RG, Dourado LK, Zampieri FG, et al. Effect of tocilizumab on clinical outcomes at 15 days in patients with severe or critical coronavirus disease 2019: Randomised controlled trial. BMJ. 2021;372:n84. Medline:33472855 doi:10.1136/bmj.n84

78 Weinreich DM, Sivapalasingam S, Norton T, Ali S, Gao H, Bhore R, et al. REGN-COV2, a Neutralizing Antibody Cocktail, in Outpatients with COVID-19. N Engl J Med. 2021;384:238-51. Medline:33332778 doi:10.1056/NEJMoa2035002

79 Eastman RT, Roth JS, Brimacombe KR, Simeonov A, Shen M, Patnaik S, et al. Remdesivir: A Review of Its Discovery and Development Leading to Emergency Use Authorization for Treatment of COVID-19. ACS Cent Sci. 2020;6:672-83. Medline:32483554 doi:10.1021/acscentsci.0c00489

80 Mulangu S, Dodd LE, Davey RT, Mbaya OT, Proschan M, Mukadi D, et al. A randomized, controlled trial of Ebola virus disease therapeutics. N Engl J Med. 2019;381:2293-303. Medline:31774950 doi:10.1056/NEJMoa1910993

81 Intensive Care National Audit and Research C. ICNARC - Reports. 2020.

82 Hung IFN, To KKW, Lee C-K, Lee K-L, Chan K, Yan W-W, et al. Convalescent Plasma Treatment Reduced Mortality in Patients With Severe Pandemic Influenza A (H1N1) 2009 Virus Infection. Clin Infect Dis. 2011;52:447-56. Medline:21248066 doi:10.1093/cid/ciq106 
83 Sanders JM, Monogue ML, Jodlowski TZ, Cutrell JB. Pharmacologic Treatments for Coronavirus Disease 2019 (COVID-19): A Review. JAMA. 2020;323:1824-36. Medline:32282022

84 Yao X, Ye F, Zhang M, Cui C, Huang B, Niu P, et al. In Vitro Antiviral Activity and Projection of Optimized Dosing Design of Hydroxychloroquine for the Treatment of Severe Acute Respiratory Syndrome Coronavirus 2 (SARS-CoV-2). Clin Infect Dis. 2020;71:732-9. Medline:32150618 doi:10.1093/cid/ciaa237

85 Tang W, Cao Z, Han M, Wang Z, Chen J, Sun W, et al. Hydroxychloroquine in patients with mainly mild to moderate coronavirus disease 2019: open label, randomised controlled trial. BMJ. 2020;369:m1849. Medline:32409561 doi:10.1136/bmj. m1849

86 Wang M, Cao R, Zhang L, Yang X, Liu J, Xu M, et al. Remdesivir and chloroquine effectively inhibit the recently emerged novel coronavirus (2019-nCoV) in vitro. Cell Res. 2020;30:269-71. Medline:32020029 doi:10.1038/s41422-020-0282-0

87 Choy KT, Wong AYL, Kaewpreedee P, Sia SF, Chen D, Hui KPY, et al. Remdesivir, lopinavir, emetine, and homoharringtonine inhibit SARS-CoV-2 replication in vitro. Antiviral Res. 2020;178:104786. Medline:32251767 doi:10.1016/j.antiviral.2020.104786

88 Sheahan TP, Sims AC, Leist SR, Schäfer A, Won J, Brown AJ, et al. Comparative therapeutic efficacy of remdesivir and combination lopinavir, ritonavir, and interferon beta against MERS-CoV. Nat Commun. 2020;11:222. Medline:31924756 doi:10.1038/ s41467-019-13940-6

89 Samuel CE. Antiviral actions of interferons. Clin Microbiol Rev. 2001;14:778-809. Medline:11585785 doi:10.1128/ CMR.14.4.778-809.2001

90 Mo Y, Fisher D. A review of treatment modalities for Middle East Respiratory Syndrome. J Antimicrob Chemother. 2016;71:3340-50. Medline:27585965 doi:10.1093/jac/dkw338

91 Sen GC. Viruses and Interferons. Annu Rev Microbiol. 2001;55:255-81. Medline:11544356 doi:10.1146/annurev.micro.55.1.255

92 Ritter JM, Flower R, Henderson G, Looke YK. Rang \& Dale’s Pharmacology. 9th ed. Amsterdam: Elsevier; 2019.

93 Ramamoorthy S, Cidlowski JA. Corticosteroids-Mechanisms of Action in Health and Disease. Rheum Dis Clin North Am. 2016:42:15-31. Medline:26611548 doi:10.1016/j.rdc.2015.08.002

94 WHO. Corticosteroids for COVID-19. 2020. Available: https://www.who.int/publications/i/item/WHO-2019-nCoV-Corticosteroids-2020.10. Accessed: 21 September 2020.

95 Guan W, Ni Z, Hu Y, Liang W, Ou C, He J, et al. Clinical characteristics of coronavirus disease 2019 in China. N Engl J Med. 2020;382:1708-20. Medline:32109013 doi:10.1056/NEJMoa2002032

96 Meduri GU, Headley AS, Golden E, Carson SJ, Umberger RA, Kelso T, et al. Effect of prolonged methylprednisolone therapy in unresolving acute respiratory distress syndrome: A randomized controlled trial. JAMA. 1998;280:159-65. Medline:9669790 doi:10.1001/jama.280.2.159

97 Brouwer PJM, Caniels TG, van der Straten K, Snitselaar JL, Aldon Y, Bangaru S, et al. Potent neutralizing antibodies from COVID-19 patients define multiple targets of vulnerability. Science. 2020. Online ahead of print. Medline:32540902 doi:10.1126/science.abc5902

98 Tian X, Li C, Huang A, Xia S, Lu S, Shi Z, et al. Potent binding of 2019 novel coronavirus spike protein by a SARS coronavirus-specific human monoclonal antibody. Emerg Microbes Infect. 2020;9:382-5. Medline:32065055 doi:10.1080/22221 751.2020 .1729069

99 Wu Y, Wang F, Shen C, Peng W, Li D, Zhao C, et al. A noncompeting pair of human neutralizing antibodies block COVID-19 virus binding to its receptor ACE2. Science. 2020;368:1274-8. Medline:32404477 doi:10.1126/science.abc2241

100 Huang M, Yang Y, Shang F, Zheng Y, Zhao W, Luo L, et al. Early and Critical Care in Severe Patients with COVID-19 Infection in Jiangsu Province, China: A Descriptive Study. SSRN Electronic Journal. 2020:1-23. doi:10.2139/ssrn.3551429

101 Alattar R, Ibrahim TBH, Shaar SH, Abdalla S, Shukri K, Daghfal JN, et al. Tocilizumab for the treatment of severe coronavirus disease 2019. J Med Virol. 2020;92:2042-2049. Medline:32369191 doi:10.1002/jmv.25964

102 Williamson BN, Feldmann F, Schwarz B, Meade-White K, Porter DP, Schulz J, et al. Clinical benefit of remdesivir in rhesus macaques infected with SARS-CoV-2. bioRxiv. 2020. doi:10.1101/2020.04.15.043166.

103 Sheahan TP, Sims AC, Graham RL, Menachery VD, Gralinski LE, Case JB, et al. Broad-spectrum antiviral GS-5734 inhibits both epidemic and zoonotic coronaviruses. Sci Transl Med. 2017;9:eaal3653. Medline:28659436 doi:10.1126/scitranslmed. aal3653

104 Mair-Jenkins J, Saavedra-Campos M, Baillie JK, Cleary P, Khaw FM, Lim WS, et al. The effectiveness of convalescent plasma and hyperimmune immunoglobulin for the treatment of severe acute respiratory infections of viral etiology: A systematic review and exploratory meta-analysis. J Infect Dis. 2015;211:80-90. Medline:25030060 doi:10.1093/infdis/jiu396

105 Soo YOY, Cheng Y, Wong R, Hui DS, Lee CK, Tsang KKS, et al. Retrospective comparison of convalescent plasma with continuing high-dose methylprednisolone treatment in SARS patients. Clin Microbiol Infect. 2004;10:676-8. Medline:15214887 doi:10.1111/j.1469-0691.2004.00956.x

106 Zhao J, Perera RAPM, Kayali G, Meyerholz D, Perlman S, Peiris M. Passive Immunotherapy with Dromedary Immune Serum in an Experimental Animal Model for Middle East Respiratory Syndrome Coronavirus Infection. J Virol. 2015;89:6117-20. Medline:25787284 doi:10.1128/JVI.00446-15

107 Corti D, Passini N, Lanzavecchia A, Zambon M. Rapid generation of a human monoclonal antibody to combat Middle East respiratory syndrome. J Infect Public Health. 2016;9:231-5. Medline:27102927 doi:10.1016/j.jiph.2016.04.003

108 Keyaerts E, Vijgen L, Maes P, Neyts J, Ranst MV. In vitro inhibition of severe acute respiratory syndrome coronavirus by chloroquine. Biochem Biophys Res Commun. 2004;323:264-8. Medline:15351731 doi:10.1016/j.bbrc.2004.08.085 
109 Dyall J, Gross R, Kindrachuk J, Johnson RF, Olinger GG, Hensley LE, et al. Middle East Respiratory Syndrome and Severe Acute Respiratory Syndrome: Current Therapeutic Options and Potential Targets for Novel Therapies. Drugs. 2017;77:193566. Medline:29143192 doi:10.1007/s40265-017-0830-1

110 Keyaerts E, Li S, Vijgen L, Rysman E, Verbeeck J, Van Ranst M, et al. Antiviral activity of chloroquine against human coronavirus OC43 infection in newborn mice. Antimicrob Agents Chemother. 2009;53:3416-21. Medline:19506054 doi:10.1128/ AAC.01509-08

111 Yao TT, Qian JD, Zhu WY, Wang Y, Wang GQ. A systematic review of lopinavir therapy for SARS coronavirus and MERS coronavirus_-A possible reference for coronavirus disease-19 treatment option. J Med Virol. 2020;92:556-63. Medline:32104907 doi:10.1002/jmv.25729

112 Wong SSY, Yuen KY. The management of coronavirus infections with particular reference to SARS. J Antimicrob Chemother. 2008;62:437-41. Medline:18565970 doi:10.1093/jac/dkn243

113 Chu CM, Cheng VCC, Hung IFN, Wong MML, Chan KH, Chan KS, et al. Role of lopinavir/ritonavir in the treatment of SARS: Initial virological and clinical findings. Thorax. 2004;59:252-6. Medline:14985565 doi:10.1136/thorax.2003.012658

114 Sung JJY, Wu A, Joynt GM, Yuen KY, Lee N, Chan PKS, et al. Severe acute respiratory syndrome: Report of treatment and outcome after a major outbreak. Thorax. 2004;59:414-20. Medline:15115870 doi:10.1136/thx.2003.014076

115 Steinberg KP, Hudson LD, Goodman RB, Hough CL, Lanken PN, Hyzy R, et al. Efficacy and Safety of Corticosteroids for Persistent Acute Respiratory Distress Syndrome. N Engl J Med. 2006;354:1671-84. Medline:16625008 doi:10.1056/NEJMoa051693

116 Jiang S, Hillyer C, Du L. Neutralizing Antibodies against SARS-CoV-2 and Other Human Coronaviruses. Trends Immunol. 2020;41:355-9. Medline:32249063 doi:10.1016/j.it.2020.03.007

117 Prather KA, Wang CC, Schooley RT. Reducing transmission of SARS-CoV-2. Science. 2020;368:1422-4. Medline:32461212 doi:10.1126/science.abc6197

118 COVID-19 vaccine development pipeline. Available: https://vac-lshtm.shinyapps.io/ncov_vaccine_landscape/. Accessed: 8 March 2021

119 Folegatti PM, Ewer KJ, Aley PK, Angus B, Becker S, Belij-Rammerstorfer S, et al. Safety and immunogenicity of the ChAdOx1 nCoV-19 vaccine against SARS-CoV-2: a preliminary report of a phase 1/2, single-blind, randomised controlled trial. Lancet. 2020;396:467-78. Medline:32702298 doi:10.1016/S0140-6736(20)31604-4

120 Ramasamy MN, Minassian AM, Ewer KJ, Flaxman AL, Folegatti PM, Owens DR, et al. Safety and immunogenicity of ChAdOxl $\mathrm{nCoV}-19$ vaccine administered in a prime-boost regimen in young and old adults (COV002): a single-blind, randomised, controlled, phase 2/3 trial. Lancet. 2021;396:1979-93. Medline:33220855 doi:10.1016/S0140-6736(20)32466-1

121 Voysey M, Clemens SAC, Madhi SA, Weckx LY, Folegatti PM, Aley PK, et al. Safety and efficacy of the ChAdOxl nCoV-19 vaccine (AZD1222) against SARS-CoV-2: an interim analysis of four randomised controlled trials in Brazil, South Africa, and the UK. Lancet. 2021;397:99-111. Medline:33306989 doi:10.1016/S0140-6736(20)32661-1

122 Pfizer. Pfizer and BioNTech Conclude Phase 3 Study of COVID-19 Vaccine Candidate, Meeting All Primary Efficacy Endpoints. 2020. Available: https://www.pfizer.co.uk/pfizer-and-biontech-conclude-phase-3-study-COVID-19-vaccine-candidate-meeting-all-primary-efficacy-endpoints. Accessed: 8 March 2021.

123 Bernal JL, Andrews N, Gower C, Stowe J, Robertson C, Tessier E, et al. Early effectiveness of COVID-19 vaccination with BNT162b2 mRNA vaccine and ChAdOxl adenovirus vector vaccine on symptomatic disease, hospitalisations and mortality in older adults in England. medRxiv. 2021. doi:10.1101/2021.03.01.21252652.

124 Vasileiou E, Simpson CR, Robertson C, Shi T, Kerr S, Agrawal U, et al. Effectiveness of First Dose of COVID-19 Vaccines Against Hospital Admissions in Scotland: National Prospective Cohort Study of 5.4 Million People. SSRN Electronic Journal. 2021. doi:10.2139/ssrn.3789264

125 Moderna. Moderna's COVID-19 Vaccine Candidate Meets its Primary Efficacy Endpoint in the First Interim Analysis of the Phase 3 COVE Study. Press. 2020.

126 Zhang Y, Zeng G, Pan H-X, Li C-G, Kan B. Immunogenicity and Safety of a SARS-CoV-2 Inactivated Vaccine in Healthy 2 Adults Aged 18-59 years: Report of the Randomized, Double-blind, and 3 Placebo-controlled Phase 2 Clinical Trial. medRxiv. 2020. doi:10.1101/2020.07.31.20161216

127 Zhu FC, Guan XH, Li YH, Huang JY, Jiang T, Hou LH, et al. Immunogenicity and safety of a recombinant adenovirus type-5vectored COVID-19 vaccine in healthy adults aged 18 years or older: a randomised, double-blind, placebo-controlled, phase 2 trial. Lancet. 2020;396:479. Medline:32702299 doi:10.1016/S0140-6736(20)31605-6

128 Sadoff J, Le Gars M, Shukarev G, Heerwegh D, Truyers C, de Groot AM, et al. Interim Results of a Phase 1-2a Trial of Ad26. COV2.S COVID-19 Vaccine. N Engl J Med. 2021. Online ahead of print. Medline:33440088 doi:10.1056/NEJMoa2034201

129 Siemieniuk RA, Bartoszko JJ, Ge L, Zeraatkar D, Izcovich A, Kum E, et al. Drug treatments for COVID-19: living systematic review and network meta-analysis. BMJ. 2020;370:m2980. Medline:32732190 doi:10.1136/bmj.m2980 